\title{
Greenhouse gas flux measurements in a forestry-drained peatland indicate a large carbon sink
}

\author{
A. Lohila ${ }^{1}$, K. Minkkinen ${ }^{2}$, M. Aurela ${ }^{1}$, J.-P. Tuovinen ${ }^{1}$, T. Penttilä ${ }^{3}$, P. Ojanen ${ }^{2}$, and T. Laurila ${ }^{1}$ \\ ${ }^{1}$ Finnish Meteorological Institute, P.O. Box 503, 00101, Helsinki, Finland \\ ${ }^{2}$ Department of Forest Sciences, University of Helsinki, P.O. Box 27, 00014 University of Helsinki, Finland \\ ${ }^{3}$ Finnish Forest Research Institute, P.O. Box 8, 01301 Vantaa, Finland
}

Received: 16 May 2011 - Published in Biogeosciences Discuss.: 21 June 2011

Revised: 20 September 2011 - Accepted: 21 October 2011 - Published: 8 November 2011

\begin{abstract}
Drainage for forestry purposes increases the depth of the oxic peat layer and leads to increased growth of shrubs and trees. Concurrently, the production and uptake of the greenhouse gases carbon dioxide $\left(\mathrm{CO}_{2}\right)$, methane $\left(\mathrm{CH}_{4}\right)$ and nitrous oxide $\left(\mathrm{N}_{2} \mathrm{O}\right)$ change: due to the accelerated decomposition of peat in the presence of oxygen, drained peatlands are generally considered to lose peat carbon $(\mathrm{C})$. We measured $\mathrm{CO}_{2}$ exchange with the eddy covariance (EC) method above a drained nutrient-poor peatland forest in southern Finland for 16 months in 20042005. The site, classified as a dwarf-shrub pine bog, had been ditched about 35 years earlier. $\mathrm{CH}_{4}$ and $\mathrm{N}_{2} \mathrm{O}$ fluxes were measured at 2-5-week intervals with the chamber technique. Drainage had resulted in a relatively little change in the water table level, being on average $40 \mathrm{~cm}$ below the ground in 2005 . The annual net ecosystem exchange was $-870 \pm 100 \mathrm{~g} \mathrm{CO}_{2} \mathrm{~m}^{-2} \mathrm{yr}^{-1}$ in the calendar year 2005, indicating net $\mathrm{CO}_{2}$ uptake from the atmosphere. The site was a small sink of $\mathrm{CH}_{4}\left(-0.12 \mathrm{~g} \mathrm{CH}_{4} \mathrm{~m}^{-2} \mathrm{yr}^{-1}\right)$ and a small source of $\mathrm{N}_{2} \mathrm{O}\left(0.10 \mathrm{~g} \mathrm{~N}_{2} \mathrm{O} \mathrm{m}^{-2} \mathrm{yr}^{-1}\right)$. Photosynthesis was detected throughout the year when the air temperature exceeded $-3^{\circ} \mathrm{C}$. As the annual accumulation of $\mathrm{C}$ in the above and below ground tree biomass $\left(175 \pm 35 \mathrm{~g} \mathrm{C} \mathrm{m}^{-2}\right)$ was significantly lower than the accumulation observed by the flux measurement $\left(240 \pm 30 \mathrm{~g} \mathrm{C} \mathrm{m}^{-2}\right)$, about $65 \mathrm{~g} \mathrm{C} \mathrm{m}^{-2} \mathrm{yr}^{-1}$ was likely to have accumulated as organic matter into the peat soil. This is a higher average accumulation rate than previously reported for natural northern peatlands, and the first time $\mathrm{C}$ accumulation has been shown by EC measurements to occur in a forestry-drained peatland. Our results suggest that forestry-drainage may significantly increase the $\mathrm{CO}_{2}$ uptake rate of nutrient-poor peatland ecosystems.
\end{abstract}

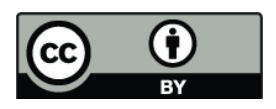

Correspondence to: A. Lohila (annalea.lohila@fmi.fi)

\section{Introduction}

One-third of the European peat soil area is located in Finland (Montanarella et al., 2006), where more than half of the original wetland area of $100000 \mathrm{~km}^{2}$ has been drained, mostly for forestry (Lappalainen, 1996). This constitutes $34 \%$ of the global area of forestry-drained peatlands; the rest of the peatlands ditched to improve forest growth are located in Russia $(26 \%)$, Sweden $(11 \%)$, other Northern European countries $(23 \%)$, North America (3\%) and China (0.5\%) (Minkkinen et al., 2008). The drainage of peatlands has been suggested to lead to rapid aerobic decomposition of organic matter and, consequently, to high carbon dioxide $\left(\mathrm{CO}_{2}\right)$ emissions and to a gradual depletion of peat carbon (C) pool (e.g. Turetsky and Louis, 2006). At the same time, methane $\left(\mathrm{CH}_{4}\right)$ emissions typically cease, in some cases even leading to $\mathrm{CH}_{4}$ uptake by the forest soil (Minkkinen et al., 2007b). Nitrous oxide $\left(\mathrm{N}_{2} \mathrm{O}\right)$ emissions may increase in minerotrophic peatlands, but not in the ombrotrophic ones (Martikainen et al., 1993; Regina et al., 1996).

Direct measurements of net ecosystem exchange (NEE) on peatlands converted to agricultural use have shown high decomposition rates of peat and large $\mathrm{C}$ losses due to drainage (Lohila et al., 2004; Veenendaal et al., 2007). Peat C loss was also observed in an afforested agricultural site 30 years after the forest had been established (Lohila et al., 2007), whereas $\mathrm{C}$ uptake on an afforested peatland in Scotland was reported by Hargreaves et al. (2003). In contrast, a moderately rich fen in Canada with naturally generated tree cover and relatively deep water table $(30-70 \mathrm{~cm})$ was found to act as a large annual $\mathrm{CO}_{2}$ sink, although this site had not been managed (Syed et al., 2006; Flanagan and Syed, 2011). To our knowledge no NEE measurements including tree canopy have been made previously in forestry-drained peatlands without agricultural history.

Studies on peat subsidence and bulk density have indicated a trend that nutrient-rich peatlands tend to lose peat

Published by Copernicus Publications on behalf of the European Geosciences Union. 
C following drainage while nutrient-poor ones may still sequester C (Minkkinen and Laine, 1998; Minkkinen et al., 1999). In forestry-drained peatlands, the nutrient status has been shown to regulate post-drainage tree stand growth (Keltikangas et al., 1986). Stand volume, in turn, regulates water table depth through transpiration (Sarkkola et al., 2009), and water table depth is the main control over the organic matter decomposition in peatlands (e.g. Silvola et al., 1996). Measurements of $\mathrm{CO}_{2}$ efflux by the chamber method have supported the idea of higher soil respiration rates in well-drained nutrient-rich sites in contrast to lesswell-drained nutrient-poor sites (Silvola et al., 1996; Minkkinen et al., 2007a; Ojanen et al., 2010).

We measured NEE above a drained peatland forest in southern Finland with the micrometeorological eddy covariance (EC) technique, which is the only viable method to monitor biosphere-atmosphere $\mathrm{CO}_{2}$ exchange of a whole forest ecosystem. Earlier, Pihlatie et al. (2010) have reported greenhouse gas (GHG) fluxes measured at this site during April-June 2007, in particular the short-term dynamics of $\mathrm{N}_{2} \mathrm{O}$ and $\mathrm{CH}_{4}$ and the effect of soil thawing on them. Here we report a full year of data on $\mathrm{CO}_{2}$ exchange of a forestrydrained peatland drained 35 years before the start of our EC measurements. These data cover a 16-month period from September 2004 to December 2005. In addition, annual dynamics and balances of $\mathrm{CH}_{4}$ and $\mathrm{N}_{2} \mathrm{O}$ fluxes are presented based on soil chamber measurements.

\section{Material and methods}

\subsection{Site presentation}

Measurements were conducted at Kalevansuo-peatland, located in the municipality of Loppi, in southern Finland $\left(60^{\circ} 38^{\prime} 49^{\prime \prime} \mathrm{N}, 24^{\circ} 21^{\prime} 23^{\prime \prime} \mathrm{E}\right.$; elevation $\left.123 \mathrm{~m}\right)$. The site, originally classified as a dwarf-shrub pine bog, was drained in 1969 with open ditches at approximately $40 \mathrm{~m}$ intervals (Fig. 1). Drainage has resulted in a slightly lowered water table (on average $40 \mathrm{~cm}$ below the ground) and has increased the growth of the natural tree stand. The topography of the site was flat. Within $160 \mathrm{~m}$ of the EC measurement mast the peat depth, measured from the 33 sample plots, varied from 1.3 to $3.0 \mathrm{~m}$, being deepest in the middle (Fig. 2). The average peat depth ( \pm standard deviation, $S D)$ was $2.2 \pm 0.5 \mathrm{~m}$. The physical and chemical properties of the peat soil (surface humus and the layers $0-10 \mathrm{~cm}$ and $10-20 \mathrm{~cm}$ below the humus) were determined from eight samples taken evenly around the measurement mast. The ash content was determined as loss on ignition $\left(550^{\circ} \mathrm{C}\right)$ and the $\mathrm{C}$ and $\mathrm{N}$ concentrations using LECO CHN-2000. Element concentrations ( $\mathrm{Al}, \mathrm{Ca}, \mathrm{Fe}, \mathrm{K}, \mathrm{Mg}, \mathrm{Mn}, \mathrm{P}, \mathrm{B}, \mathrm{Cu}, \mathrm{Mn}, \mathrm{Zn}$ ) were measured by an ICP Iris emission spectrometer in dry-ashed material. The bulk density of the peat varied from 0.08 to $0.11 \mathrm{~g} \mathrm{~cm}^{-3}$ at the depths of $0-10 \mathrm{~cm}$ and $10-20 \mathrm{~cm}$, respectively (Table 1 ).

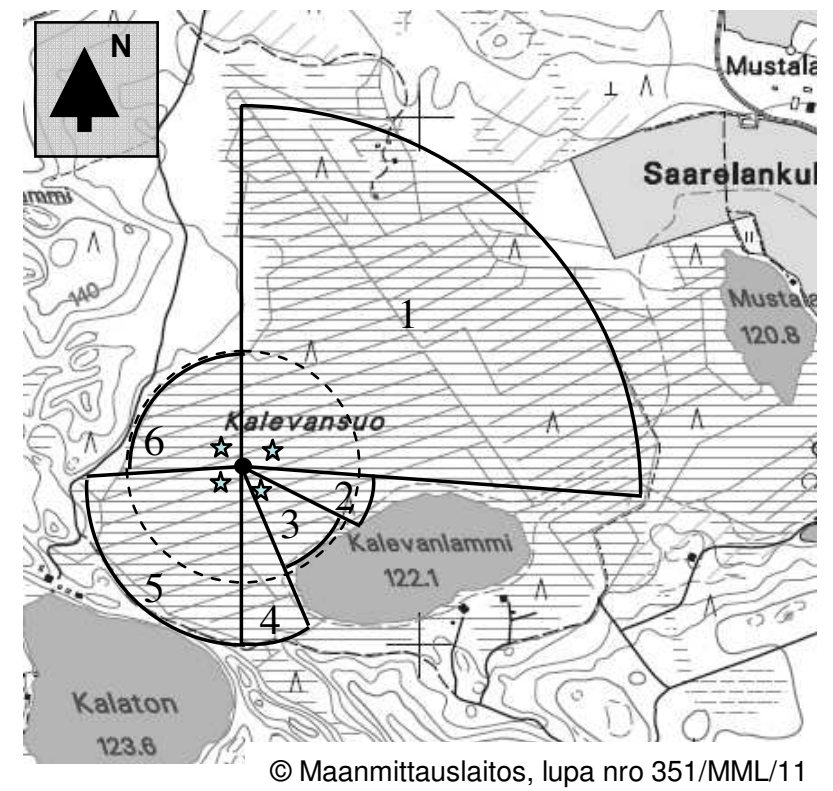

Fig. 1. Map of the Kalevansuo drained peatland showing the location of the EC measurement mast (black circle) and the chamber measurement plots (stars). The black solid lines indicate the borders of the sectors (1-6) used in the footprint analysis. The dashed circle shows the distance of $200 \mathrm{~m}$ from the mast. The main drainage ditch that empties towards the south-east and the smaller ditches that empty into the main ditch have been indicated by the gray solid lines. The two ponds, Kalaton and Kalevanlammi, located on the borders of the site are indicated in the map together with their elevation from the sea level.

The CN-ratio was high, varying from 34 to 41 , the lowest values being measured at a depth of $0-10 \mathrm{~cm}$. The concentrations of most of the measured elements were highest in the humus layer and lowest deeper in the peat (Table 1). The $\mathrm{pH}$ of the peat was 5.0 (Pihlatie et al., 2010). The concentration of soil $\mathrm{NO}_{3}^{-}$was negligible, whereas the $\mathrm{NH}_{4}^{+}$concentration in the peat varied between 5 and $15 \mathrm{mg} \mathrm{N} \mathrm{kg}^{-1}$ and that of dissolved $\mathrm{N}$ between 75 and $225 \mathrm{mg} \mathrm{N} \mathrm{kg}^{-1}$ soil (Pihlatie et al., 2010).

Basic tree stand variables for the biomass calculations (diameter, height) were measured from 33 plots $\left(500 \mathrm{~m}^{2}\right)$ in eight radial transects extending $160 \mathrm{~m}$ from the EC mast (Fig. 2). Biomasses were estimated with the functions of Repola $(2008,2009)$ and Laiho and Finér (1996) for aboveground and belowground components, respectively. The tree stand consisted of a dominant Scots pine (Pinus sylvestris) stand of 835 stems ha ${ }^{-1}$, and an understorey of pubescent birch (Betula pubescens) trees $\left(<500\right.$ stems ha $\left.^{-1}\right)$ that were mainly found on the ditch banks. Scots pine constituted $63 \%$ of the number of trees taller than $1.3 \mathrm{~m}$ and $98 \%$ of the stand volume. The pine stand had a dominant height of $15 \mathrm{~m}$, a basal area of $17 \mathrm{~m}^{2} \mathrm{ha}^{-1}$, and the annual stem volume growth was $5.5 \mathrm{~m}^{3} \mathrm{ha}^{-1} \mathrm{yr}^{-1}$. The annual increment of 
Table 1. Soil characteristics and element concentrations at the surface peat at Kalevansuo.

\begin{tabular}{|c|c|c|c|c|c|c|c|c|c|c|c|c|c|c|c|c|}
\hline Soil layer & $\begin{array}{l}\text { Bulk density } \\
\left(\mathrm{kg} \mathrm{m}^{-3}\right)\end{array}$ & Ash content $\%$ & $\mathrm{C}(\%)$ & $\mathrm{N}(\%)$ & $\mathrm{C} / \mathrm{N}$ & $\mathrm{Al}^{1}$ & $\mathrm{Ca}^{1}$ & $\mathrm{Fe}^{1}$ & $\mathrm{~K}^{1}$ & $\mathrm{Mg}^{1}$ & $\mathrm{Mn}^{1}$ & $\mathrm{P}^{1}$ & $\mathrm{~B}^{1}$ & $\mathrm{Cu}^{1}$ & $\mathrm{Mn}^{1}$ & $\mathrm{Zn}^{1}$ \\
\hline Humus & - & 2.4 & 49 & 1.2 & 41 & 210 & 4000 & 260 & 3100 & 880 & 260 & 1000 & 4.6 & 5.5 & 260 & 63 \\
\hline $0-10 \mathrm{~cm}$ & $81 \pm 9$ & 2.9 & 50 & 1.5 & 34 & 800 & 2400 & 1000 & 470 & 460 & 56 & 680 & 1.9 & 4.7 & 56 & 56 \\
\hline $10-20 \mathrm{~cm}$ & $106 \pm 8$ & 2.0 & 51 & 1.4 & 38 & 740 & 1300 & 950 & 140 & 260 & 5.2 & 450 & 0.73 & 1.4 & 5.2 & 16 \\
\hline
\end{tabular}

1 total amount of the element in $\mathrm{mg} \mathrm{kg}^{-1}$

$2 \pm$ denotes standard deviation

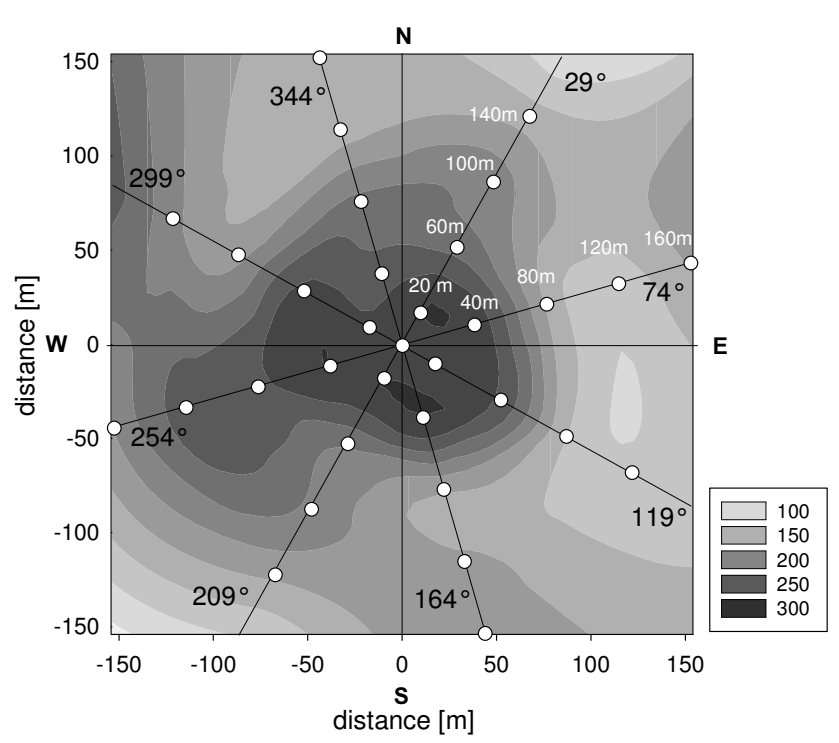

Fig. 2. Peat depth $(\mathrm{cm})$, interpolated as a contour plot, around the EC flux measurement mast $($ at $(0,0))$ at Kalevansuo. The white circles show the locations of the tree stand and peat depth measurement points $(n=33)$, with the directions of lines and the distances of points from the EC mast indicated. The lines $344^{\circ}$ and $164^{\circ}$ were perpendicular to the drainage ditches, while the lines $74^{\circ}$ and $254^{\circ}$ were parallel to the ditches. The distances from the centre of the plot on lines $119^{\circ}, 209^{\circ}$ and $299^{\circ}$ follow those depicted for line $29^{\circ}$, and the distances of the points on lines $164^{\circ}, 254^{\circ}$ and $344^{\circ}$ follow those depicted for line $74^{\circ}$.

live tree stand biomass was $3.52 \mathrm{t}$ of dry mass $\mathrm{ha}^{-1}$, corresponding to about $175 \mathrm{~g} \mathrm{C} \mathrm{m}^{-2} \mathrm{yr}^{-1}$ (see Appendix B2 for uncertainty analysis). During the summertime maximum biomass, the all-sided leaf area index (LAI) of the needles estimated from the needle mass, was $5 \mathrm{~m}^{2} \mathrm{~m}^{-2}$. The field layer was dominated by Ledum palustre, Vaccinium uliginosum, V. vitis-idaea, V. myrtillus, Empetrum nigrum, Calluna vulgaris, Eriophorum vaginatum and Rubus chamaemorus. The bottom layer was dominated by forest-mosses Pleurozium schreberi, Dicranum polysetum, Aulacomnium palustre and Polytrichum strictum with some peat-mosses like Sphagnum angustifolium, S. magellanicum and S. russowii on the wetter spots. Mosses cover about $90 \%$ of the land surface at Kale- vansuo. The one-sided LAI of the field layer varied from 0.1 to $0.6 \mathrm{~m}^{2} \mathrm{~m}^{-2}$ during the course of the growing season (Badorek et al., 2011).

\subsection{Measurements of the $\mathrm{CO}_{2}$ exchange and meteorological variables}

The turbulent fluxes of $\mathrm{CO}_{2}, \mathrm{H}_{2} \mathrm{O}$, sensible heat and momentum were measured with the eddy covariance technique on top of a $21.5 \mathrm{~m}$ telescopic mast (at $17.5 \mathrm{~m}$ from April 2005). Fluctuations of wind velocity components were measured with a sonic anemometer/thermometer (SATI-3SX, Applied Technologies, Inc.) and those of $\mathrm{CO}_{2}$ concentration with a closed-path infrared $\mathrm{CO}_{2} / \mathrm{H}_{2} \mathrm{O}$ analyzer (LI-7000, LI-COR, Inc.). The heated inlet tube (3.1 mm Bevaline IV) for the LI7000 was $17 \mathrm{~m}$ in length, and a flow rate of $61 \mathrm{~min}^{-1}$ was used. $\mathrm{CO}_{2}$-free synthetic dry air was used as a reference gas. From February 2005 onwards, the mean $\mathrm{CO}_{2}$ concentration $\left(\left[\mathrm{CO}_{2}\right]\right)$ was also observed at a height of $4 \mathrm{~m}$ with a LI-820 $\mathrm{CO}_{2}$ analyzer. Both analyzers were calibrated monthly with two known $\left[\mathrm{CO}_{2}\right]$ (0 and $\left.421 \mathrm{ppm}\right)$. The fluxes were calculated on-line as $30 \mathrm{~min}$ averages as described by Pihlatie et al. (2010), taking into account the density fluctuations related to the water vapour flux (Webb et al., 1980). The results were corrected for systematic flux losses using the transfer function method of Moore (1986), including the losses due to autoregressive running mean filtering and the imperfect high-frequency response of the measurement system. For the former, the transfer function presented by Moore (1986) was used, while for the latter an empirical transfer function representing the overall system response was determined from the field data using the sensible heat flux as a reference (with a half power frequency of $1.6 \mathrm{~Hz}$ for the $\mathrm{CO}_{2}$ flux); for details, see Laurila et al. (2005). Idealized cospectral distibutions (Kaimal and Finnigan, 1994) were assumed. The flux-loss corrections were carried out as a post-processing step and implemented as look-up tables of wind speed and stability dependent correction factors.

The storage flux of $\mathrm{CO}_{2}$ was estimated from the $\left[\mathrm{CO}_{2}\right]$ data measured at the top of the mast and at the height of $4 \mathrm{~m}$ by assuming that these represent $\left[\mathrm{CO}_{2}\right]$ from $8 \mathrm{~m}$ to the measurement height and from the ground to $8 \mathrm{~m}$, respectively. The storage term was calculated with the central difference 
method from the mean concentration during the subsequent and preceding $30 \mathrm{~min}$ periods and added to the measured turbulent flux (hereafter NEE refers to the sum of turbulent and storage fluxes). However, before 21 February 2005, the storage flux was calculated from the $\left[\mathrm{CO}_{2}\right]$ measured at the top of the mast only, with the assumption that it represented the whole air column below that height. In this paper, we use the convention that a positive value of NEE indicates a flux from the ecosystem to the atmosphere.

Supporting meteorological measurements were conducted at the study site as follows: air temperature $\left(T_{\text {air }}\right)$ and relative humidity (RH) (Vaisala HMP230) at $2 \mathrm{~m}$ and at the top of the mast, soil temperature (PT100) at depths of 0.05 , 0.15 and $0.30 \mathrm{~m}$ in a moist hollow, and at $0.05 \mathrm{~m}$ in a hummock, soil moisture (ThetaProbe ML2x, Delta-T Devices Ltd.) at depths of 0.07 and $0.30 \mathrm{~m}$, soil heat flux (HFP01) at a depth of $0.15 \mathrm{~m}$, net radiation (Kipp\&Zonen NR Lite), global and reflected global radiation (LI-200SZ), photosynthetic photon flux density (PPFD) and reflected PPFD (Licor LI-190SZ) at the top of the mast, and the water table level (WTL) (PDCR 830). The data were acquired using a Vaisala QLI 50 and Campbell CR10X1 sensor collectors and stored as $30 \mathrm{~min}$ averages. The snow depth and the precipitation data, as well as the $T_{\text {air }}$ data in cases of data collection failure at the Kalevansuo site were collected from four nearby weather stations operated by the Finnish Meteorological Institute (Maasoja/station code 0309, Mutila/1302, Nurmijärvi/1321 and Jokioinen/1201, at distances of $19-53 \mathrm{~km}$, on average $29.5 \mathrm{~km}$, from the site). For climatic comparisons, long-term data were used from stations 0309, 1201 and 1302 . To cover the spatial variation, manual measurements of WTL were carried out at bimonthly intervals from eight perforated plastic pipes, which were located in four directions within a distance of ca. $50 \mathrm{~m}$ from the EC mast. The half-hourly water table data were then calibrated against the average WTL from these manual measurements.

\section{$2.3 \mathrm{CO}_{2}$ flux data screening}

Longer gaps in the $\mathrm{CO}_{2}$ flux data were mainly caused by power failure, sensor malfunction and freezing of the anemometer. The longest gaps took place on 2-13 April 2005, 7-11 August 2005, 21 August-5 September 2005 and 9-24 November 2005. The remaining $30 \mathrm{~min}$ data records were screened according to the following criteria: (1) $\left[\mathrm{CO}_{2}\right]>350 \mathrm{ppm}$, (2) number of spikes in the vertical wind speed $(w)$ and $\left[\mathrm{CO}_{2}\right]$ raw data $<180$, (3) variances of the raw data $\sigma_{T_{\text {air }}}^{2}<3 \mathrm{~K}^{2}, \sigma_{\mathrm{CO}_{2}}^{2}<50 \mathrm{ppm}^{2}$ and $\sigma_{w}^{2}<3 \mathrm{~m}^{2} \mathrm{~s}^{-2}$ and (4) $-40^{\circ} \mathrm{C}<T_{\text {air }}<40^{\circ} \mathrm{C}$.

In order to estimate how well the measured fluxes represent the Scots pine stand around the measurement mast, a source area analysis was carried out with a micrometeorological footprint model. The relative source weight functions (flux footprints) were calculated for each $30 \mathrm{~min}$ averaging period using the footprint model of Kormann and Meixner

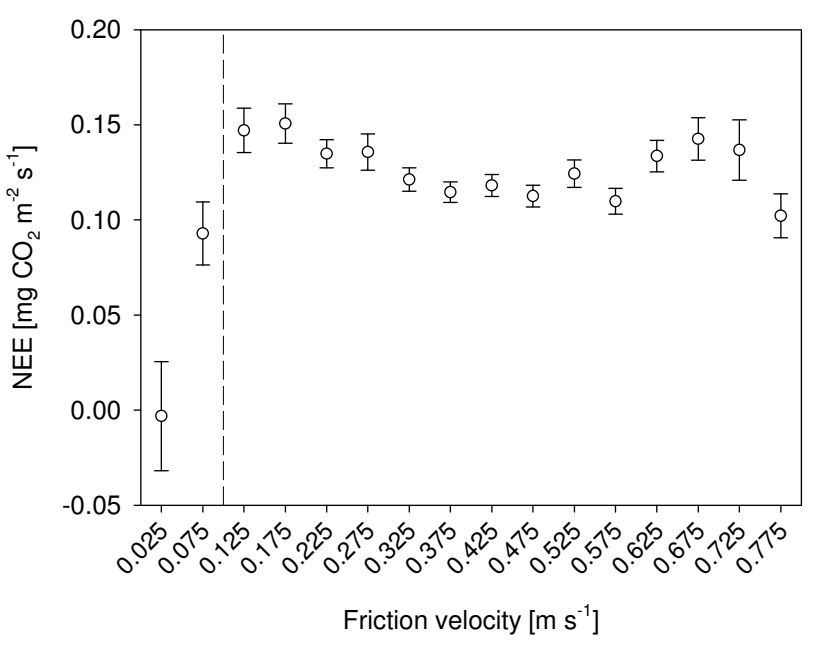

Fig. 3. Average night-time $\mathrm{CO}_{2}$ flux ( \pm standard error) in the growing season 2005 plotted against the friction velocity. Data were grouped into $u_{*}$ classes of $0.05 \mathrm{~m} \mathrm{~s}^{-1}$. The $u_{*}$ limit below which the data was rejected from the further analysis, $0.1 \mathrm{~m} \mathrm{~s}^{-1}$, is indicated with the dashed line.

(2001). The horizontal dimension of the stand was defined as six circular sectors (Fig. 1), and the modelled (cross-windintegrated) footprint was accumulated over the radius of the sector corresponding to the observed wind direction. If this cumulative footprint was larger than $70 \%$, the flux data of that period were considered sufficiently representative of the peatland forest and accepted for further analysis. Owing to the high surface roughness, the source areas were concentrated relatively close to the measurement mast with the typical distance of the footprint maximum being less than $30 \mathrm{~m}$.

During suppressed turbulence (typically summer nights), part of the $\mathrm{CO}_{2}$ produced by ecosystem respiration may accumulate near the surface and be advected below the measurement height, in which case the measured vertical flux is likely to underestimate NEE. Therefore we rejected the NEE data from further analysis if the friction velocity $\left(u_{*}\right)$ was below $0.10 \mathrm{~m} \mathrm{~s}^{-1}$ (Fig. 3). This threshold was defined as the upper limit of the lowest $u_{*}$ class with a mean NEE value significantly different from that of the next class. The difference between these mean values $\left(\mathrm{NEE}_{i}\right.$ and $\left.\mathrm{NEE}_{i+1}\right)$ was considered significant if the $95 \%$ confidence intervals, defined as

$\left(\mathrm{NEE}_{i+1}-\mathrm{NEE}_{i}\right) \pm 2 \sqrt{\mathrm{SE}_{i+1}^{2}+\mathrm{SE}_{i}^{2}}$

where $\mathrm{SE}_{i}$ is the standard error of $\mathrm{NEE}_{i}$, did not cross zero.

By applying the footprint and $u_{*}$ criteria, an additional $17 \%$ of the data were discarded. After filtering the data according to the quality criteria shown above, altogether a total of 10959 flux values $(47.3 \%$ ) of the 30 min periods during the whole measurement period (11 September 2004-31 December 2005) were accepted and used in the further analysis. Of these, night-time data accounted for $49 \%(n=5361)$. 


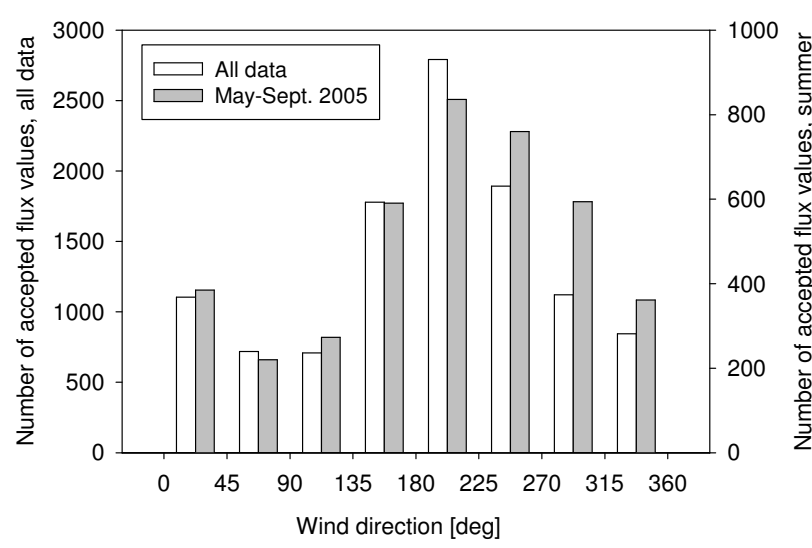

Fig. 4. Number of the accepted $\mathrm{CO}_{2}$ flux data separated into different wind direction sectors at $45^{\circ}$ intervals. Data are shown for the periods of September 2004-December 2005 (white bars) and May-September 2005 (gray bars) (note different y-axes).

Most of the data were related to the south-western and southern wind directions, whereas the contribution of other directions was more evenly distributed (Fig. 4). During the growing season, most of the data originated from the southwest, and the least data from the north-east and east.

Energy balance closure at the site was $91 \%$ $\left(y=0.91 x+11.2 \mathrm{~W} \mathrm{~m}^{-2}\right.$, where $x$ is net radiation and $y$ is the sum of sensible and latent heat flux, $R^{2}=0.86$ ), indicating a relatively small imbalance as compared to typical values in forests, 10-30\% (Wilson et al., 2002). We did not adjust the measured NEE with the energy balance.

\subsection{Gap-filling of NEE}

In order to gap-fill the $\mathrm{CO}_{2}$ flux time-series, which is required to calculate the $\mathrm{CO}_{2}$ balances, and for the analysis of seasonal patterns of the flux components, the measured $\mathrm{CO}_{2}$ flux was partitioned by means of empirical equations into gross primary production (GPP) and total ecosystem respiration $\left(R_{\mathrm{tot}}\right) . R_{\mathrm{tot}}$ was modelled as a function of temperature using the Arrhenius-type model of Lloyd and Taylor (1994):

$R_{\text {tot }}=R_{\text {ref }} \times \exp \left[E_{0} \times\left(\frac{1}{T_{\text {ref }}}-\frac{1}{T_{\text {air }}-227.13}\right)\right]$

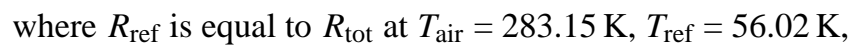
and $E_{0}$ is the temperature sensitivity of the respiration (in $\mathrm{K})$. Air temperature measured at $2 \mathrm{~m}$ height was used for $T_{\text {air }}$ (in K). $T_{\text {air }}$ was selected since a full time-series was easily available and a slightly higher correlation was obtained for $T_{\text {air }}$ than for soil temperature.

NEE was modelled using PPFD and the modelled $R_{\text {tot }}$ as input values to the following equation:

$\mathrm{NEE}=\mathrm{GPP}+R_{\mathrm{tot}}$

$\mathrm{NEE}=f_{\mathrm{VPD}} \times\left(\frac{\alpha \times \mathrm{PPFD} \times \mathrm{GP}_{\max }}{\alpha \times \mathrm{PPFD}_{\mathrm{GP}} \mathrm{GP}_{\max }}\right)+R_{\mathrm{tot}}$ where $\alpha$ is the apparent quantum yield and $G P_{\max }$ is the full daylight asymptotic value of NEE after subtracting the modelled $R_{\mathrm{tot}} . \quad f_{\mathrm{VPD}}$ is a unitless function that was estimated based on the linear relationship between the measured NEE (with PPFD > $1000 \mu \mathrm{mol} \mathrm{m}^{-2} \mathrm{~s}^{-1}$ ) and atmospheric vapour pressure deficit (VPD) in July. $f_{\mathrm{VPD}}$ was given a value of 1 when $\mathrm{VPD}<10 \mathrm{hPa}$, and a value of 0.2 when $\mathrm{VPD}>25 \mathrm{hPa}$. These are within the typical limits of observed VPD effects in Scots pine forests (Mills et al., 2010).

The parameter fitting procedure is presented in more detail in Appendix A. The daily, seasonal and annual $\mathrm{CO}_{2}$ balances were calculated from the full time-series consisting of measured and gap-filled half-hourly $\mathrm{CO}_{2}$ flux data. The error analysis of the $\mathrm{CO}_{2}$ balance and tree $\mathrm{C}$ accumulation estimates is described in Appendix B.

\subsection{Chamber measurements of $\mathrm{CH}_{4}$ and $\mathrm{N}_{2} \mathrm{O}$ fluxes}

Chamber measurements were carried out in $2-5$-week intervals between 7 July 2004 and 17 September 2005. The $\mathrm{CH}_{4}$ and $\mathrm{N}_{2} \mathrm{O}$ fluxes were measured with static chambers at 16 sampling points located in four directions (plots 14) each at a distance of about $50 \mathrm{~m}$ from the EC mast (Fig. 1). Round, metallic chambers (diameter $=0.315 \mathrm{~m}$, height $=0.30 \mathrm{~m}$ ) equipped with a fan for mixing the air in the chamber headspace were used. During the measurement, the chamber was placed in a $0.02 \mathrm{~m}$ deep collar that had been carefully installed on the soil to ensure sealing but not to cut any root connections. In winter, when the snowpack was deeper than $0.10 \mathrm{~m}$, fluxes were measured with the help of an $0.10 \mathrm{~m}$ deep collar inserted on the snowpack prior to measurement. Four air samples $(20 \mathrm{ml})$ were drawn into syringes at $10 \mathrm{~min}$ intervals $(5,15,25,35 \mathrm{~min})$. The samples were analysed within $24 \mathrm{~h}$ using a gas chromatograph with flame ionisation and electron capture detectors in the laboratory of the Finnish Forest Research Institute, Vantaa Unit.

Gas fluxes were calculated from the change of the gas concentration over time (slope estimated by linear regression). All data were used, regardless of the goodness of fit of the regression, as in most cases the fluxes were very small and close to the detection limit (below $0.4 \mathrm{mg} \mathrm{m}^{-2} \mathrm{day}^{-1}$ ). Fluxes exceeding $0.4 \mathrm{mg} \mathrm{m}^{-2} \mathrm{day}^{-1}$ had minimum/mean $R^{2}$ values of 0.63/0.91 $\left(\mathrm{CH}_{4}\right)$ and $0.67 / 0.90\left(\mathrm{~N}_{2} \mathrm{O}\right)$. Four measurements were deleted as a result of chamber sealing problems in winter. As the site was well drained, no ebullition events were observed, so the data represents diffusive or/and plant-mediated gas fluxes. During each chamber measurement, the soil temperatures at 0.05 and $0.30 \mathrm{~m}$ were recorded and the WTL relative to each sampling point was measured from perforated water wells.

Annual $\mathrm{CH}_{4}$ and $\mathrm{N}_{2} \mathrm{O}$ balances were calculated as the mean of the 16 plots for each measurement day. Mean fluxes between these days were linearly interpolated and seasonal fluxes were then integrated from these interpolated daily fluxes. 


\section{Results}

\subsection{Meteorological conditions and water table level}

The measurement period from September 2004 to December 2005 was slightly warmer and wetter than average: at the three nearby weather stations $(0309,1302$ and 1201) the mean annual temperature during the period varied from 5.0 to $5.5^{\circ} \mathrm{C}$ as calculated for consecutive 365 -day periods during the measurement period, whereas the mean annual long-term (1971-2000) temperature was $4.4^{\circ} \mathrm{C}$ (Drebs et al., 2002). Annual precipitation during the measurement period ranged from 615 to $701 \mathrm{~mm}$, which is similar or slightly higher than the long-term average of $627 \mathrm{~mm}$. In 2005 , annual mean temperature and precipitation were $5.2{ }^{\circ} \mathrm{C}$ and $626 \mathrm{~mm}$, respectively. Daily mean temperatures varied from -16 to $22^{\circ} \mathrm{C}$. The first snow appeared on the ground on 18 November 2004, but by 20 January 2005 , the snow-pack had melted twice during warm spells. Thereafter, snow was present until mid-April with the maximum depth of $37 \mathrm{~cm}$ being measured on 14 February. The largest deviations from the longterm monthly mean temperatures were observed in January, March and November 2005 (Fig. 5). The monthly precipitation exceeded the 30-year mean between May and August and also in January and November 2005. In contrast, September and October 2005 were especially dry. During the study period, the WTL ranged from -31 to $-50 \mathrm{~cm}$, being deepest in mid-October 2005.

\subsection{Seasonal dynamics and factors affecting the $\mathrm{CO}_{2}$ exchange}

The seasons were defined according to meteorological conditions. The start of the autumn season took place when the daily mean air temperature dropped permanently below $10^{\circ} \mathrm{C}$, and after that did not exceed $10^{\circ} \mathrm{C}$ for more than two consecutive days. In 2004, when autumn started on 29 September, the amplitude of the diurnal NEE cycle was still rather high, but began to decline soon after this (Fig. 6). In 2005 , the autumn period began on 12 October. The start of winter was defined as the first day when the daily mean temperature was less than $0^{\circ} \mathrm{C}$, and that the temperature stayed below $0^{\circ} \mathrm{C}$ for at least five consecutive days. The winter seasons, which began on 17 November and 16 November in 2004 and 2005, respectively, were characterized by a low amplitude in NEE, which varied from -0.005 to $0.1 \mathrm{mg} \mathrm{m}^{-2} \mathrm{~s}^{-1}$ and averaged $0.025 \mathrm{mg} \mathrm{m}^{-2} \mathrm{~s}^{-1}$. We defined the start of the spring season as the first day when the daily mean temperature exceeded $0{ }^{\circ} \mathrm{C}$, and remained above that value for at least 10 consecutive days. The start of the spring, 31 March, likely coincided with the rapid increase in the $\mathrm{CO}_{2}$ uptake, although the exact date is unknown due to a gap in the measurement data. Summer was specified to begin when the daily mean temperature exceeded $10^{\circ} \mathrm{C}$ for five consecutive days, and afterwards did not drop below that value for more

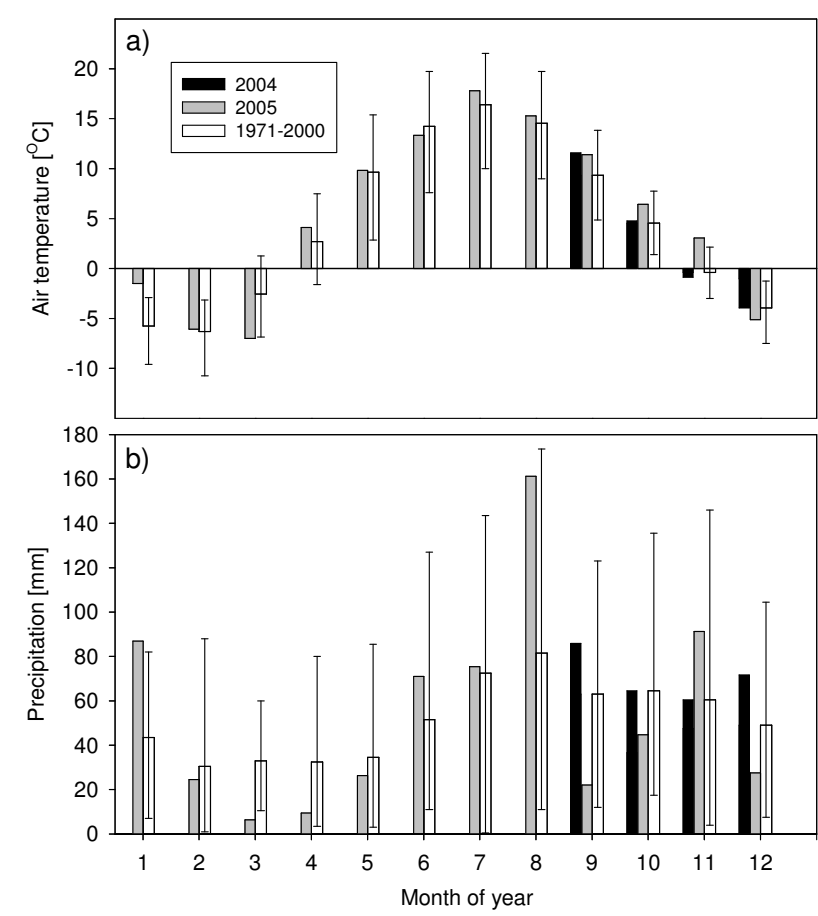

Fig. 5. (a) Monthly mean temperature and (b) monthly cumulative precipitation during the study period and in 1971-2000. The bars indicate the range between the minimum and maximum values.

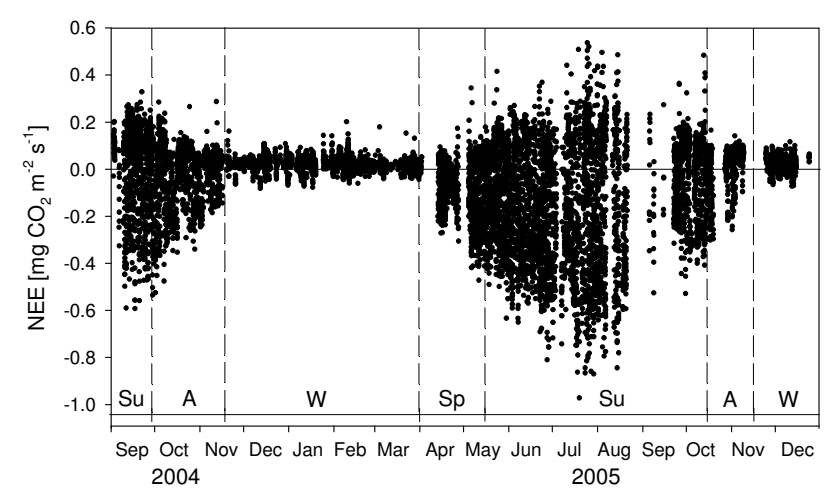

Fig. 6. Time series of the accepted half-hourly measurements of the $\mathrm{CO}_{2}$ exchange at Kalevansuo in September 2004-December 2005. Positive values indicate emission of $\mathrm{CO}_{2}$ from the ecosystem to the atmosphere. Letters indicate meteorologically defined seasons $(\mathrm{Su}=$ summer, $\mathrm{A}=$ autumn, $\mathrm{W}=$ winter, $\mathrm{Sp}=$ spring $)$.

than five consecutive days. This took place on 10 May 2005. The highest uptake rates of about $-0.85 \mathrm{mg} \mathrm{m}^{-2} \mathrm{~s}^{-1}$ were observed at the end of July, at about the same time as the maximum night-time respiration of about $0.45 \mathrm{mg} \mathrm{m}^{-2} \mathrm{~s}^{-1}$.

Although NEE was mainly positive in winter, periods of small uptake of $\mathrm{CO}_{2}$ were detected occasionally, particularly between November 2004 and mid-February 2005. We found that when temperatures fell below $-3{ }^{\circ} \mathrm{C}, \mathrm{CO}_{2}$ fluxes 


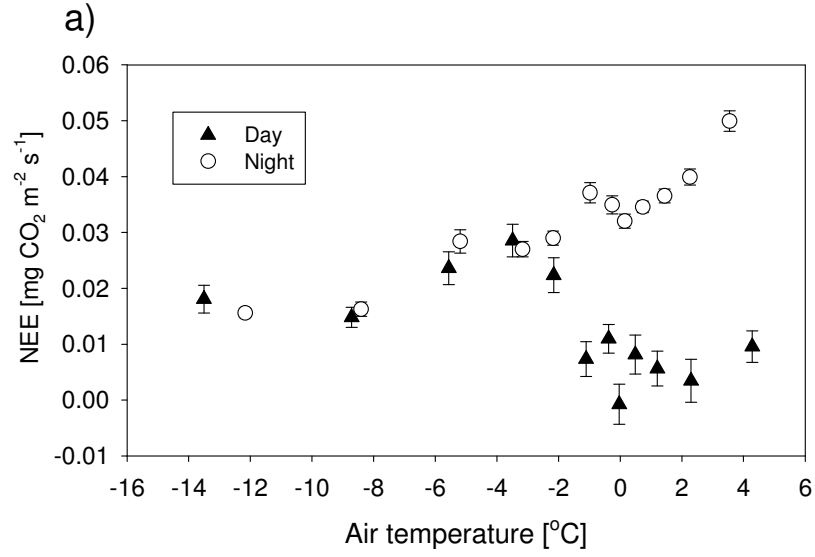

b)

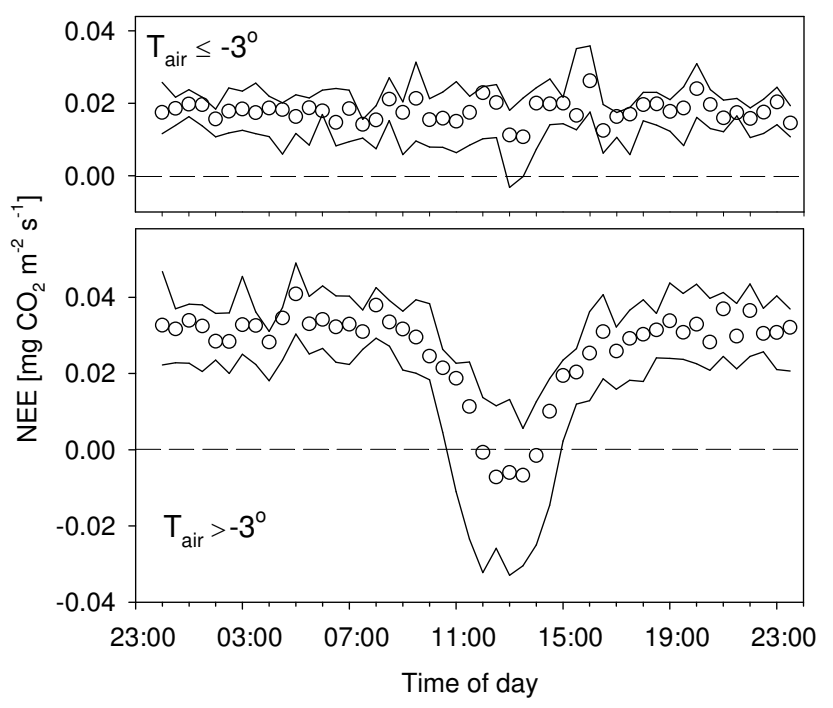

Fig. 7. (a) Average ( \pm standard error) nocturnal and day-time (PPFD $<1$ and PPFD $>1 \mu \mathrm{mol} \mathrm{m}^{-2} \mathrm{~s}^{-1}$, respectively) NEE plotted against air temperature in winter. The data are grouped into 12 classes with equal amount of observations $(n=170$ and $n=93$ in night and day, respectively). (b) Half-hourly medians ( \pm 25 th and 75th percentiles) of measured NEE in winter when air temperature is below $-3^{\circ} \mathrm{C}$ (upper graph) and above $-3{ }^{\circ} \mathrm{C}$ (lower graph).

measured during the daytime and night-time were similar, increasing with higher temperature (Fig. 7a). When the air temperature exceeded $-3^{\circ} \mathrm{C}$, the difference between the day and night fluxes increased rapidly due to $\mathrm{CO}_{2}$ uptake by the trees and ground vegetation during the daytime. When $T_{\text {air }}$ was lower than $-3^{\circ} \mathrm{C}$, the diurnal variation in NEE disappeared, whereas with higher temperatures, a clear pattern with $\mathrm{CO}_{2}$ uptake peaking at noon was observed (Fig. 7b).

Irradiance is generally recognized as the most important variable causing diurnal variation in growing season NEE also. This was also observed at the Kalevansuo peatland forest. However, a significant correlation between VPD and the 30 min NEE was observed in May-August (Fig. 8). The correlation was strongest in July with the deepest regression slope and the highest coefficient of determination being observed then. However, since temperature and VPD are likely to show a positive correlation, it is possible that the correlation between NEE and VPD can be attributed to increased respiration rather than decreased photosynthesis. To determine the impact of $T_{\text {air }}$ and VPD on ecosystem processes, we grouped the July NEE observations at full radiation (PPFD > $1200 \mu \mathrm{mol} \mathrm{m}^{-2} \mathrm{~s}^{-1}$ ) into temperature classes of $1^{\circ} \mathrm{C}$. In each class, a linear correlation between NEE and VPD was observed (Fig. 9). However, the correlation was not explained by the temperature (Fig. 9).

\section{3 $\mathrm{CO}_{2}$ balance}

In 2005, annual $R_{\text {tot }}$ was $2750 \mathrm{~g} \mathrm{CO}_{2} \mathrm{~m}^{-2}, \quad$ GPP was $-3620 \mathrm{~g} \mathrm{CO}_{2} \mathrm{~m}^{-2}$ and annual $\mathrm{NEE}$ was $-871 \pm 100 \mathrm{~g} \mathrm{CO}_{2} \mathrm{~m}^{-2} \quad\left(-238 \pm 27 \mathrm{~g} \mathrm{C} \mathrm{m}^{-2} \mathrm{yr}^{-1}\right)$, where \pm denotes the uncertainty estimate (see Appendix B1). If calculated using a moving 365-day window over the whole period (2 September 2004-31 December 2005), the annual balance ranged from -806 to $-898 \mathrm{~g} \mathrm{CO}_{2} \mathrm{~m}^{-2} \mathrm{yr}^{-1}$, the highest NEE (lowest net $\mathrm{CO}_{2}$ uptake) being observed during an annual period starting on 2 September 2004.

In autumn 2004, the daily $\mathrm{CO}_{2}$ balance varied from -5 to $10 \mathrm{~g} \mathrm{~m}^{-2} \mathrm{day}^{-1}$, the ecosystem being a sink during warm and sunny days and a source during overcast days (Fig. 10). After mid-November (start of the winter), photosynthesis ceased, and the daily balance turned positive. Wintertime NEE was on average $2.0 \mathrm{~g} \mathrm{CO}_{2} \mathrm{~m}^{-2} \mathrm{day}^{-1}$. During the winter months, the lowest average NEE was measured in March $\left(1.6 \mathrm{~g} \mathrm{CO}_{2} \mathrm{~m}^{-2} \mathrm{day}^{-1}\right)$. This was attributed to the low respiration rate following the lowest monthly mean temperature, rather than to the occurrence of $\mathrm{CO}_{2}$ uptake, which was only observed during a few days. At the beginning of April and during the spring season, the forest turned to a $\mathrm{CO}_{2}$ sink. With a few exceptions, the ecosystem acted as a $\mathrm{CO}_{2}$ sink until mid-September. During this period, positive daily $\mathrm{CO}_{2}$ balances were only observed during cloudy days, e.g. 8-11 August 2005, when the precipitation sum exceeded $50 \mathrm{~mm}$. In 2005 , the length of the sink period was approximately 210 days, ending at the beginning of November, two weeks after the end of summer and two weeks before the start of winter. Again, a strong reduction in photosynthesis coincided exactly with the beginning of the winter season.

The contribution of the wintertime photosynthesis on the seasonal and annual balances was estimated by calculating the balance by different methods. First, the $\mathrm{CO}_{2}$ balance for the winter period (17 November 2004-30 March 2005) was calculated as a sum of the modelled respiration (Eq. 2). The result, $286 \mathrm{~g} \mathrm{CO}_{2} \mathrm{~m}^{-2}$, represents a situation where no photosynthesis occurred during winter. If calculated as a sum of the measured and modelled values, then gap-filling with the modelled respiration data results in a balance of $279 \mathrm{~g} \mathrm{CO}_{2} \mathrm{~m}^{-2}$. In this estimate, winter photosynthesis is 


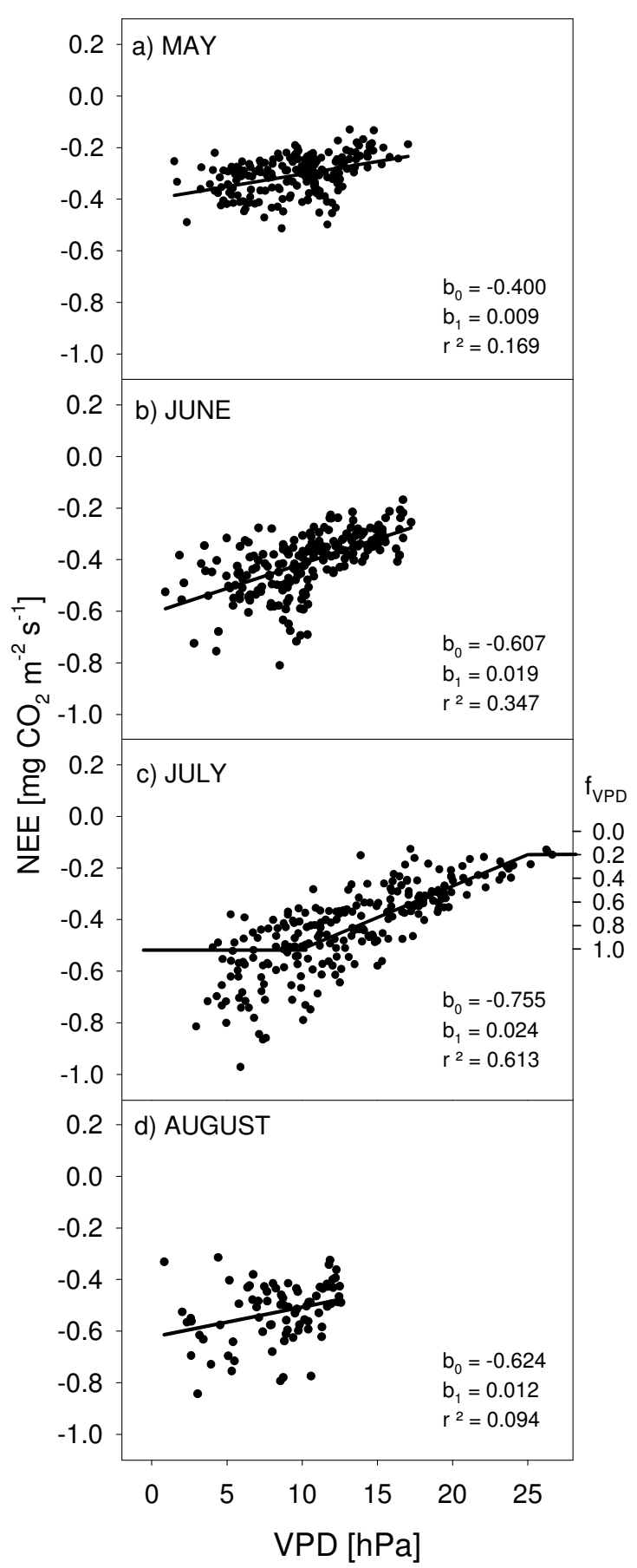

Fig. 8. Half-hourly NEE measured during high irradiance $\left(\right.$ PPFD $>1000 \mu \mathrm{mol} \mathrm{m}^{-2} \mathrm{~s}^{-1}$ ) plotted against vapour pressure deficit (VPD) in May-August 2005. The parameter values of the linear regression $\left(\mathrm{NEE}=b_{0}+b_{1} \times \mathrm{VPD}\right)$ are shown. In (c) the line shows the $f_{\mathrm{VPD}}$ function used in Eq. (4), defined according to the regression for the July data.
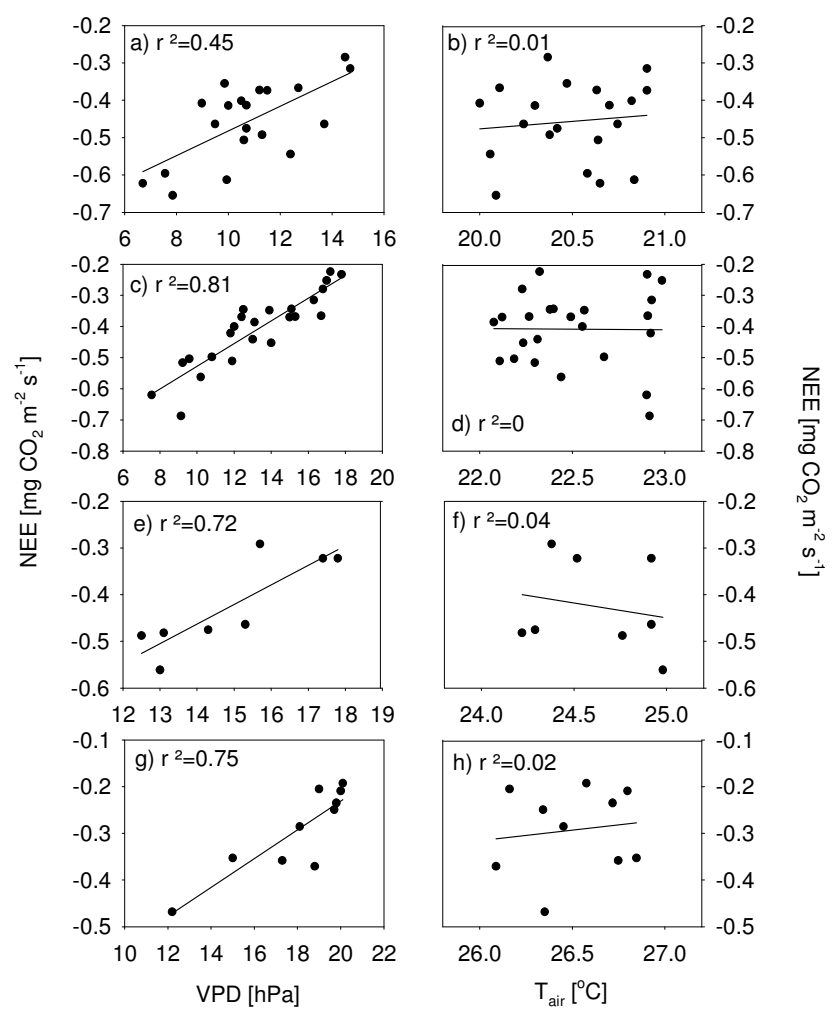

Fig. 9. Measured half-hourly NEE $\left(\operatorname{PPFD}>1200 \mu \mathrm{mol} \mathrm{m}^{-2} \mathrm{~s}^{-1}\right)$ plotted against VPD (left panel) and air temperature (right panel) in temperature ranges $20-21^{\circ} \mathrm{C}(\mathbf{a}, \mathbf{b}), 22-23^{\circ} \mathrm{C}(\mathbf{c}, \mathbf{d}), 24-25^{\circ} \mathrm{C}(\mathbf{e}$, f) and $26-27^{\circ} \mathrm{C}(\mathbf{g}, \mathbf{h})$. Parallel plots represent the same NEE data.

accounted for in that part of the data where accepted records exist. However, since the gap-filling was done with Eq. 2, which ignores photosynthesis, NEE is potentially overestimated when $T_{\text {air }}>-3^{\circ} \mathrm{C}$. If the gaps were filled using Eq. (4) that includes the radiation-response, the wintertime $\mathrm{CO}_{2}$ balance was $264 \mathrm{~g} \mathrm{~m}^{-2}$. This method represented the best estimate and was used in the calculation of the wintertime and annual balances presented in this paper.

\section{4 $\mathrm{CH}_{4}$ and $\mathrm{N}_{2} \mathrm{O}$ fluxes between the soil and the atmosphere}

The site was a small sink of $\mathrm{CH}_{4}$ $\left(-0.35 \pm 0.58 \mathrm{mg} \mathrm{CH}_{4} \mathrm{~m}^{-2} \mathrm{day}^{-1} ;\right.$ mean $\left.\pm \mathrm{SD}\right)$ and a small source of $\mathrm{N}_{2} \mathrm{O}\left(0.30 \pm 0.25 \mathrm{mg} \mathrm{N}_{2} \mathrm{O} \mathrm{m}^{-2}\right.$ day $\left.^{-1}\right)$. $\mathrm{N}_{2} \mathrm{O}$ fluxes were very similar at all 16 sampling points (Fig. 11): no statistical differences were detected (ANOVA; $p=0.358$ ). In contrast, $\mathrm{CH}_{4}$ fluxes varied between the sampling points $(p<0.001)$, and ranged from sample points with a small consumption to points with small emissions (Fig. 11). Surprisingly, the highest consumption $\left(-1.0 \pm 0.5 \mathrm{mg} \mathrm{m}^{-2} \mathrm{day}^{-1}\right)$ of $\mathrm{CH}_{4}$ was measured at plot 2, which also had the highest WTL, whereas 


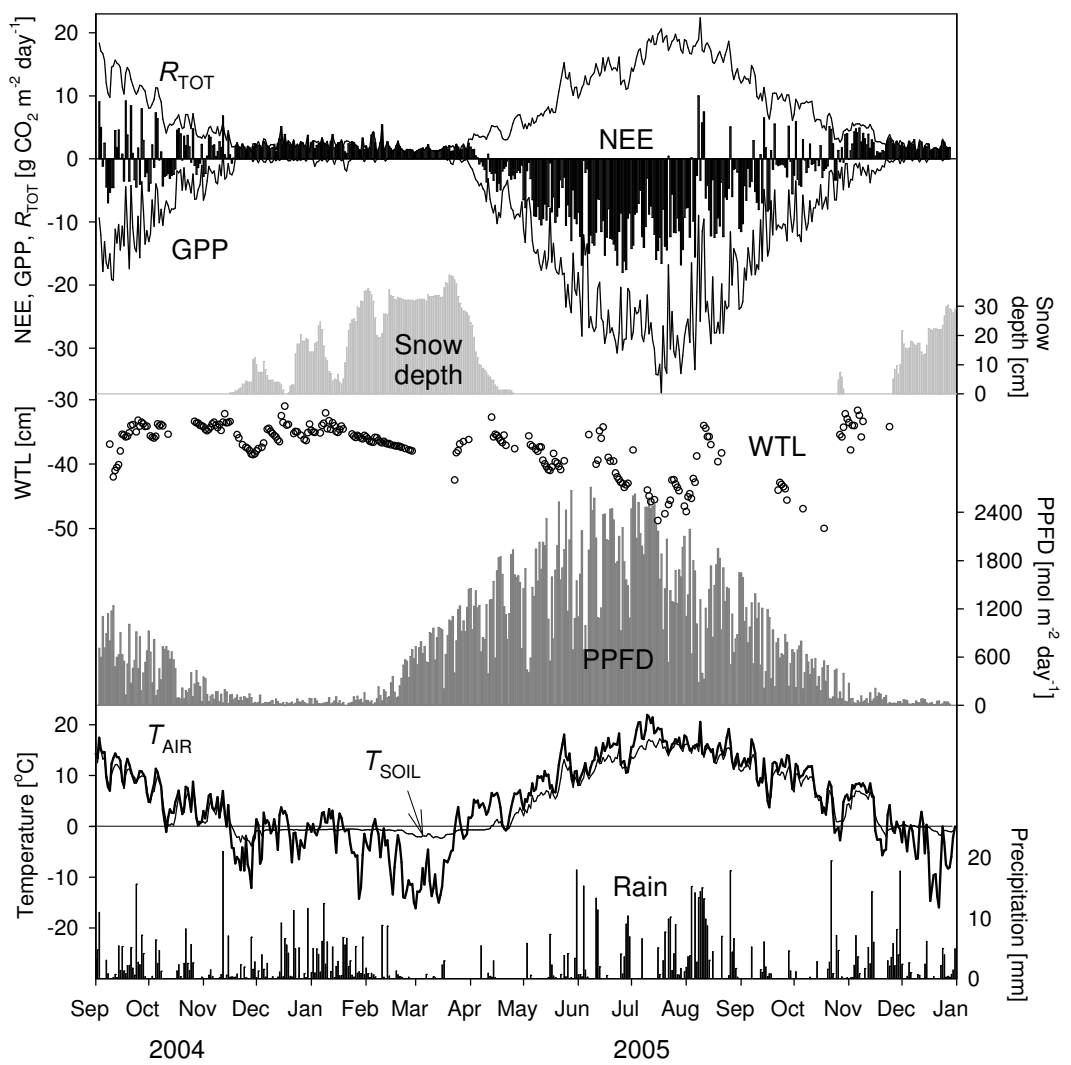

Fig. 10. Daily NEE (top black bars), modelled $R_{\text {tot }}$ and GPP (lines in the upper panel), snow depth (light gray bars), water table level (WTL; open circles), daily cumulative photosynthetic radiation (PPFD, dark gray bars), daily air temperature (thick line in the bottom), daily soil temperature at $5 \mathrm{~cm}$ depth (thin line in the bottom), and precipitation (black bars in the bottom) at Kalevansuo peatland forest from September 2004 to December 2005. The snow depth and precipitation data represent the average of the four nearest weather stations.

the highest emissions $\left(0.02 \pm 0.40 \mathrm{mg} \mathrm{m}^{-2} \mathrm{day}^{-1}\right)$ were measured at plot 1 with the deepest water levels. Emissions showed no correlation with the plant community (forest mosses/Sphagnum), nor with the microtopography (hummock/non-hummock) (Fig. 11). $\mathrm{CH}_{4}$ consumption and $\mathrm{N}_{2} \mathrm{O}$ emissions peaked at midsummer, although some high $\mathrm{N}_{2} \mathrm{O}$ emissions were also detected in winter (Fig. 12). The highest $\mathrm{CH}_{4}$ emissions were detected in autumn 2005 at plots 3 and 4 .

The seasonal and annual fluxes were integrated from the interpolated fluxes (Fig. 12). The growing season (MaySeptember) fluxes were on average $-58 \mathrm{mg} \mathrm{CH}_{4} \mathrm{~m}^{-2}$ and $47 \mathrm{mg} \mathrm{N}_{2} \mathrm{O} \mathrm{m}^{-2}$ and the annual fluxes (August 2004-July 2005) were $-120 \mathrm{mg} \mathrm{CH}_{4} \mathrm{~m}^{-2}$ and $100 \mathrm{mg} \mathrm{N}_{2} \mathrm{O} \mathrm{m}^{-2}$. When converted to global warming potential values using a time horizon of 100 years (Forster et al., 2007), the annual emissions were -3 and $30 \mathrm{~g} \mathrm{CO}_{2}$ eq. $\mathrm{m}^{-2}$.

\section{Discussion}

\subsection{Annual uptake of $\mathrm{CO}_{2}$ exceeds peat decomposition}

In this paper we have reported a significant $\mathrm{CO}_{2}$ sink in a drained peatland forest in southern Finland. Ombrotrophic treed peatlands, such as the Kalevansuo site presented in this study, constitute over $10 \%$ of the total area (5.4-5.7 million ha) of peatlands ever drained for forestry in Finland (Minkkinen et al., 2002), and the site type (dwarf-shrub type) is the single most commonly drained one in southern Finland. Such sites therefore have general importance in regard to their impacts on global-scale GHG balances and climate, for example.

The annual net $\mathrm{CO}_{2}$ uptake at our site $\left(240 \pm 30 \mathrm{~g} \mathrm{C} \mathrm{m}^{-2}\right)$ was very likely higher than the amount of $\mathrm{C}$ accumulated in the tree biomass $\left(175 \pm 35 \mathrm{~g} \mathrm{C} \mathrm{m}^{-2}\right)$, which indicates that the forest floor, i.e. the ground layer vegetation and the underlying peat must also have constituted a C sink. In general, the mineralisation rate of peat should increase after drainage, since lowering of the water level increases the aeration of the surface peat (Laine et al., 2006; Nykänen et al., 1995; 

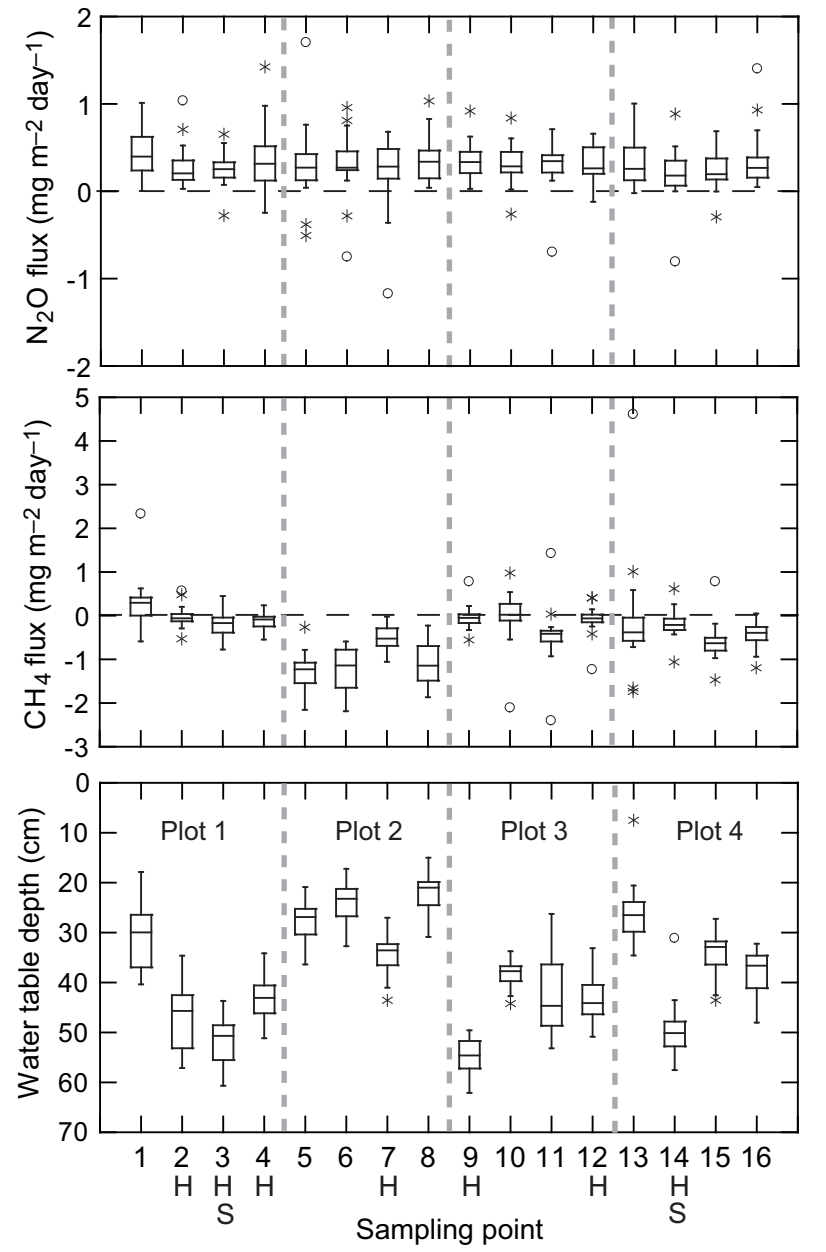

Fig. 11. Box plot of $\mathrm{N}_{2} \mathrm{O}$ and $\mathrm{CH}_{4}$ fluxes and water table depths in 16 sampling points at four plots around the EC mast in the Kalevansuo drained peatland forest. $\mathrm{H}=$ hummock, $\mathrm{S}=$ Sphagnumdominated community (others forest-moss-dominated). The box plot shows the distribution of the data: The box shows the quartiles (lower edge $25 \%$, upper edge $75 \%$ ) and median (band inside box) of the data. The whiskers show data that falls within $1.5 \times$ box height (interquartile range, IQR) and asterisks show the data points within $3 \times$ IQR. Circles show data that fall outside these limits and are considered outliers (Systat 12, Systat software).

Silvola et al., 1996; Maljanen et al., 2001; Veenendaal et al., 2007). On the other hand, the annual NEE reported here supports the findings from peat subsidence and $\mathrm{C}$ stock studies by Minkkinen and Laine (1998) and Minkkinen et al. (1999), who showed that nutrient-poor peatland types may continue to sequester $\mathrm{C}$ after drainage for forestry.

Nutrient-poor sites are typically situated in the thickpeated, relatively flat centre area of bogs. In those conditions drainage by ditching may not work out as well as in the mire margins due to peat subsidence and blockage of ditches by vegetation. Therefore, water tables in nutrient-poor sites remain relatively high, keeping peat decomposition rates at moderate levels (e.g. Silvola et al., 1996; Ojanen et al.,

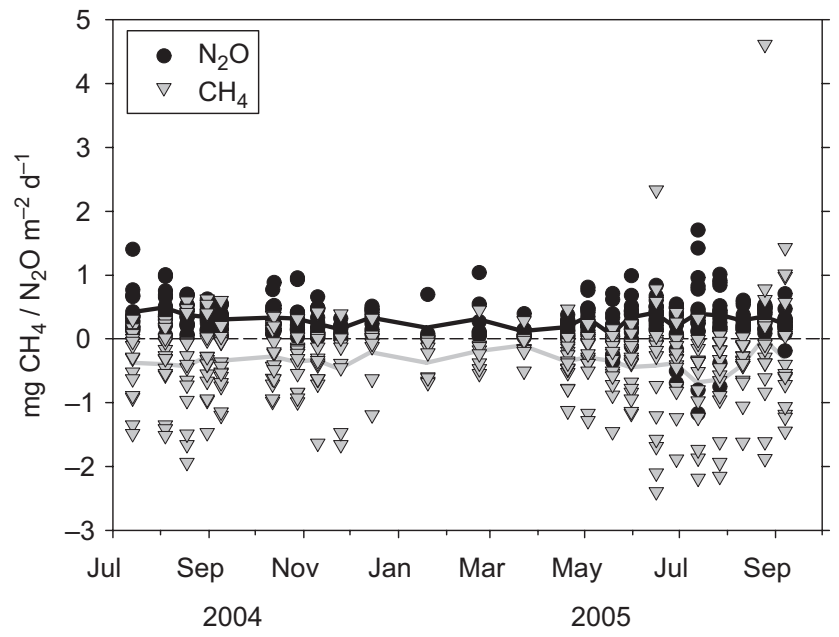

Fig. 12. Observed (circle and triangle), mean, and interpolated (black and grey lines) daily $\mathrm{N}_{2} \mathrm{O}$ and $\mathrm{CH}_{4}$ fluxes, measured by closed chambers in 24 days at Kalevansuo during 2004-2005.

2010). At Kalevansuo, the drainage has resulted in an average water table level of $-40 \mathrm{~cm}$. As a typical water level in pristine dwarf-shrub pine bogs is approximately $-20 \mathrm{~cm}$ (Silvola et al., 1996; Minkkinen et al., 1999), the WTL drawdown at Kalevansuo has not been more than $20 \mathrm{~cm}$. However, even this small drawdown has enhanced the tree growth, which is clearly seen in the annual rings, the width of which has increased after the 1970s (results not shown).

The lower peat decomposition rate and the higher allocation of $\mathrm{C}$ into the roots with low nutrient availability (Minkkinen, 1999) as well as the lush, actively photosynthesising ground vegetation (Badorek et al., 2011) could explain the $\mathrm{C}$ accumulation into this nutrient-poor peatland ecosystem. There is also an increase in the input of slow decomposing woody and moss litter and a decrease in the input of fasterdecomposing grasses and herbs (Laiho et al., 2003). Furthermore, the quantity of the aboveground litterfall increases dramatically after the drainage which may compensate or even exceed the decomposition of the old $\mathrm{C}$ in the peat (Straková et al., 2010, 2011). In addition, part of the $C$ released from the decayed litter is translocated as a solute to deeper peat layers and contributes to the $\mathrm{C}$ accumulation in the peat (Domisch et al., 2000).

We did not measure $\mathrm{C}$ leaching from the ecosystem. As the site was rather flat, water discharge was very slow apart from the snowmelt events. Most of the ditches were blocked by vegetation and therefore functioned poorly. It was therefore likely that the drainage at the site was maintained mainly by the transpiration of the tree stand, which is a typical situation in drained peatland forests in Finland (Hökkä et al., 2008). Leaching of dissolved carbon from Finnish drained peatlands typically results in a loss of about 10 to $15 \mathrm{~g} \mathrm{C} \mathrm{m}^{-2} \mathrm{yr}^{-1}$ (Sallantaus and Kaipainen, 1996; Kortelainen et al., 1997; 
Sarkkola et al., 2009; Rantakari et al., 2010). On the other hand, $\mathrm{C}$ is also imported into the peatland from surrounding landscapes and in deposition. In pine forests in Finland, the flux of dissolved organic carbon varies from 2 to $6 \mathrm{~g} \mathrm{C} \mathrm{m}^{-2} \mathrm{yr}^{-1}$ in stand throughfall and from 2 to $10 \mathrm{~g} \mathrm{C} \mathrm{m}^{-2} \mathrm{yr}^{-1}$ in percolation water (Lindroos et al., 2008). Typically leaching is higher from organic, C-rich soils, so it can be assumed that more $\mathrm{C}$ was lost than was received from surface waters, but this amount is likely to be so small that it has little significance for the $\mathrm{C}$ balance at this site.

We are not aware of other year-round NEE measurements conducted on forestry-drained peatlands. If we also consider other peatland types, the annual $\mathrm{CO}_{2}$ uptake at our site is the highest among the published values. Flanagan and Syed (2011) reported an average annual sink of $690 \mathrm{~g} \mathrm{CO}_{2} \mathrm{~m}^{-2}$ over a six-year period in a natural treed fen in Canada. At their site, the average annual GPP $\left(-3100 \mathrm{~g} \mathrm{CO}_{2} \mathrm{~m}^{-2}\right)$ and $R_{\text {tot }}\left(2400 \mathrm{~g} \mathrm{CO}_{2} \mathrm{~m}^{-2}\right)$ were lower than at our site $(-3600$ and $2800 \mathrm{~g} \mathrm{CO}_{2} \mathrm{~m}^{-2}$ ). Even though their site was natural (undrained), it had as deep or deeper average water table (30$70 \mathrm{~cm}$ ) than our ditched site, indicating similar aeration in the peat soil. Lowered water table in dry years did not increase $\mathrm{C}$ loss from the system, since the increased respiration was compensated by increased photosynthesis.

Higher annual $\mathrm{CO}_{2}$ balances (i.e. lower $\mathrm{C}$ accumulation and/or higher emission) have been measured on bogs with sparse or absent tree cover. In Scotland, the annual NEE of a drained ombrotrophic peatland used for sheep grazing varied from -350 to $-500 \mathrm{~g} \mathrm{CO}_{2} \mathrm{~m}^{-2} \mathrm{yr}^{-1}$ (Dinsmore et al., 2010), while in southern Sweden, in an undrained bog with a low tree cover, it was about $-80 \mathrm{~g} \mathrm{CO}_{2} \mathrm{~m}^{-2}$ (Lund et al., 2007). In an ombrotrophic bog with only very small trees in Canada, the annual NEE varied from -40 to $-280 \mathrm{~g} \mathrm{CO}_{2} \mathrm{~m}^{-2}$ (Lafleur et al., 2003), and in an Irish maritime blanket bog with no tree cover NEE ranged between -45 and $-310 \mathrm{~g} \mathrm{CO}_{2} \mathrm{~m}^{-2}$ during six years (Koehler et al., 2011). At this site, a significant proportion of $C$ was lost through leaching and $\mathrm{CH}_{4}$ emission, resulting in an average annual $\mathrm{C}$ balance of $-50 \mathrm{~g} \mathrm{C} \mathrm{m}^{-2}$.

In contrast, the annual net $\mathrm{CO}_{2}$ balance was close to zero in a well-drained afforested peatland with an agricultural history in Finland, indicating that the peat decomposition rate outweighed the $\mathrm{C}$ accumulation in trees (Lohila et al., 2007). Since the tree growth rate was substantial, this showed that the peat was still vigorously decomposing 30 years after the afforestation. Using combined snap-shot measurements and modelling, Hargreaves et al. (2003) suggested that conifer plantations in Scotland may become net sinks of $\mathrm{CO}_{2}$ around 4-8 years after afforestation. However, in contrast to our results, after subtracting the tree $\mathrm{C}$ accumulation component of NEE, the peat at their ecosystem showed a net loss of $\mathrm{CO}_{2}$ at a rate of $370 \mathrm{~g} \mathrm{~m}^{-2} \mathrm{yr}^{-1}$.

Direct measurements of the sub-canopy $\mathrm{CO}_{2}$ fluxes have indicated that the ground layer of Kalevansuo was a $\mathrm{C}$ source in April-June (Pihlatie et al., 2010). However, this sub-canopy flux consists of not only the NEE of the peat and ground layer vegetation, but also the tree root respiration. Since the contribution of the root-derived respiration to GPP may vary from about 10 to $50 \%$ (Moyano et al., 2009), it is likely that the sum of the tree root and peat respiration overrides the $\mathrm{CO}_{2}$ sink of the ground vegetation.

It is interesting to note that the NEE at Kalevansuo was similar to that observed in the Hyytiälä Scots pine forest, located $150 \mathrm{~km}$ to the north of Kalevansuo (Ilvesniemi et al., 2009). In addition to the same dominating tree species, the total volume and mean height of the trees are rather similar at these sites. The most significant difference between the sites is the underlying soil type, which is haplic podzol at Hyytiälä. At this site, the annual balance has varied between -510 and $-920 \mathrm{~g} \mathrm{CO}_{2} \mathrm{~m}^{-2}$ over a ten-year period (Ilvesniemi et al., 2009). The annual GPP and $R_{\text {tot }}$ were slightly higher at Hyytiälä, -3800 and $3000 \mathrm{~g} \mathrm{CO}_{2} \mathrm{~m}^{-2}$, respectively, against -3600 and $2800 \mathrm{~g} \mathrm{CO}_{2} \mathrm{~m}^{-2}$ at Kalevansuo. The higher GPP values at Hyytiälä are expected, since the trees are younger and the soil condition and nutrition is more favourable for the tree growth there than at Kalevansuo. Therefore, the trees at Hyytiälä are growing faster, accumulating $240 \mathrm{~g} \mathrm{C} \mathrm{m}^{-2} \mathrm{yr}^{-1}$ (Ilvesniemi et al., 2009), i.e. $40 \%$ more than the tree stand at Kalevansuo $\left(175 \mathrm{~g} \mathrm{C} \mathrm{m}^{-2}\right)$. On the other hand, the ground vegetation at Kalevansuo is denser and contributes more to the observed NEE than that at Hyytiälä. The contribution of the ground vegetation is likely to explain why the observed difference in NEE between Hyytiälä and Kalevansuo is smaller than expected on the basis of the tree $\mathrm{C}$ accumulation at the sites.

\subsection{On the factors controlling NEE}

Irradiation was not the only significant meteorological variable controlling diurnal dynamics of $\mathrm{CO}_{2}$ exchange during the growing season. In addition, there was a significant correlation between NEE and VPD, indicating suppression of the photosynthesis of the peatland vegetation under drier conditions. Since NEE is a sum of $R_{\text {tot }}$ and GPP, the relationship between NEE and VPD could be partially explained by the increased $R_{\text {tot }}$ with higher air temperatures, in addition to the suppressed assimilation. Using standardized environmental conditions we still found a significant correlation between the NEE and VPD (Fig. 9), suggesting that the relationship could be attributed to stomatal closure rather than an increase in ecosystem respiration due to higher temperatures. The strong control of VPD is somewhat surprising, as the maximum distance of the ground water level was only about 50 $\mathrm{cm}$ from the peat surface in summer (Fig. 10). Hence, water should be rather easily available for the tree roots. The relationship reflects the immediate response of needle stomata to VPD and suggests that the ecosystem $\mathrm{C}$ uptake may be weakened during a dry spell due to stomatal restrictions, although water is available for roots. A similar phenomenon of lowered $\mathrm{CO}_{2}$ uptake during drought has been observed 
in natural open peatlands (Lafleur et al., 2003; Aurela et al. 2007, 2009) and in non-peatland forests (e.g., Luyssaert et al., 2007; Lasslop et al., 2010).

Removing the VPD response function $\left(f_{\mathrm{VPD}}\right)$ from the NEE-model (Eq. 4) would reduce the fit between the modelled and measured values only slightly $\left(R^{2}=0.86\right.$ against $R^{2}=0.88$ ). However, using $f_{\mathrm{VPD}}$ corrected the deviation from the linearity observed at the lowest end of the data (i.e., high $\mathrm{CO}_{2}$ uptake values) (results not shown), indicating the importance of VPD for the gap-filling modelling during dry periods.

We observed $\mathrm{CO}_{2}$ uptake at our forest site throughout the winter. In January, for example, when the monthly mean temperature was $-1.2^{\circ} \mathrm{C}$, photosynthesis was observed when $T_{\text {air }}$ exceeded $-3^{\circ} \mathrm{C}$. In February and March (mean temperatures of $-6.6^{\circ} \mathrm{C}$ and $-8.0^{\circ} \mathrm{C}$, respectively), photosynthesis was detected only occasionally. Wintertime assimilation by trees has been also reported to take place in the Hyytiälä forest (Sevanto et al., 2006), but photosynthesis was not observed in January there, possibly due to low radiation levels. Sevanto et al. (2006) also observed $\mathrm{CO}_{2}$ uptake by tree shoots in air temperatures as low as $-7^{\circ} \mathrm{C}$. At Kalevansuo, a higher $T_{\text {air }}\left(>-3{ }^{\circ} \mathrm{C}\right)$ was needed for photosynthesis to take place. Our results show that $\mathrm{CO}_{2}$ uptake may occur in boreal forests throughout the year, depending on meteorological conditions.

By ignoring the wintertime $\mathrm{CO}_{2}$ uptake in the gap-filling the estimated $\mathrm{CO}_{2}$ emission during the winter would increase by $8 \%$, but the effect on the annual balance would be less than $3 \%$. It can be concluded therefore that the contribution of the wintertime $\mathrm{CO}_{2}$ uptake to the annual balance was not significant, at least in a winter like 2004-2005 at Kalevansuo. In warmer winters, however, a larger significance of wintertime photosynthesis can be anticipated. It is recommended that at such boreal sites where temperatures close to zero occur regularly, the winter photosynthesis should be taken into account by including an appropriate light response model in gap-filling methods.

\subsection{GHG balance and global warming potentials}

The annual balance of $\mathrm{CH}_{4}$ uptake $\left(-0.12 \mathrm{~g} \mathrm{~m}^{-2} \mathrm{yr}^{-1}\right)$ and $\mathrm{N}_{2} \mathrm{O}$ emission $\left(0.10 \mathrm{~g} \mathrm{~m}^{-2} \mathrm{yr}^{-1}\right)$ for Kalevansuo are in line with those measured from the same (dwarf-shrub) site type in an extensive study covering the whole Finland (Ojanen et al., 2010) and with those measured during a three-month period at the same site (Pihlatie et al., 2010). $\mathrm{CH}_{4}$ emissions in natural, undrained bogs, such as Kalevansuo before drainage, are on average $6 \mathrm{~g} \mathrm{~m}^{-2} \mathrm{yr}^{-1}$ (Saarnio et al., 2007). In general, $\mathrm{CH}_{4}$ emissions are strongly reduced after drainage, and in many cases, $\mathrm{CH}_{4}$ oxidation in the peat surface overrides the production deeper in the soil. The resulting $\mathrm{CH}_{4}$ uptake is more typical of fens than bogs with the poorest sites with weakest tree growth often acting as a postdrainage source of $\mathrm{CH}_{4}$ (Martikainen et al., 1995; Minkkinen et al., 2007b). Considering the climatic impact of an annual emission/uptake pulse of the three greenhouse gases at Kalevansuo, $\mathrm{CO}_{2}$ was by far the most significant one. Therefore it can be concluded that the drainage of this peatland has not resulted in the site having a net warming impact on climate.

\section{Conclusions}

This study presents the first year-round NEE data measured on forestry-drained peatland and supports earlier results, obtained by measuring changes in the peat $\mathrm{C}$ store that demonstrated that nutrient-poor peatland forests may accumulate $\mathrm{C}$ at the same or even increased rates after drainage. During a 16-month period in 2004-2005, the annual NEE at Kalevansuo varied between -810 and $-900 \mathrm{~g} \mathrm{CO}_{2} \mathrm{~m}^{-2}$, depending on the start of the period. The increase in tree biomass only explained about $70 \%$ of the $\mathrm{C}$ sink. No increase was observed in the ground vegetation biomass either. Therefore, it is likely that $\mathrm{C}$ is accumulated into the soil as dead organic matter, i.e., the soil is accumulating $\mathrm{C}$ as is typical for natural, undrained peatlands. This may be attributed to the increased woody litter input and below-ground productivity, as well as the continuous abundance of peat and forest mosses at the site. Simultaneously, the decomposition of soil organic matter has remained at a moderate level because of only a moderate drop in the water table. $\mathrm{N}_{2} \mathrm{O}$ emissions had not increased dramatically after the drainage, contributing less than $5 \%$ to the climatic impact of this ecosystem in its current state. $\mathrm{CH}_{4}$ uptake by the forest soil was practically negligible in comparison with the high cooling impact caused by the net $\mathrm{CO}_{2}$ uptake. Following on from this study, the fate of $\mathrm{CO}_{2}$ in the ecosystem should be examined in detail, to understand the mechanisms in the soil and ground vegetation which contribute to the excess $\mathrm{C}$ accumulation and the high $\mathrm{CO}_{2}$ sink at this site. With such understanding, the results could be more easily generalized by incorporating them into biogeochemical process models.

\section{Appendix A}

\section{Gap-filling of the $\mathrm{CO}_{2}$ exchange data}

To estimate $E_{0}$ outside the winter, Eq. (2) was fitted to the night-time (PPFD $<1 \mu \mathrm{mol} \mathrm{m}{ }^{-2} \mathrm{~s}^{-1}$ ) NEE data in time windows of 15 days, shifting the window five days at a time. $E_{0}$, (constrained to $>100 \mathrm{~K}$ ), was averaged over all periods where (1) the number of data points exceeded 40 , (2) the temperature range exceeded $5 \mathrm{~K}$ and (3) $E_{0}<450 \mathrm{~K}$, resulting in $E_{0}=225 \mathrm{~K}$ and $E_{0}=173 \mathrm{~K}$ for the periods of 2 September18 November 2004 and 11 April-17 November 2005, respectively. The number of accepted/discarded $E_{0}$ values was $23 / 0$ and 30/8 in 2004 and 2005, respectively. Thereafter, $R_{\text {ref }}$ was estimated for the same periods as described above using 
Eq. (2) and the constant $E_{0}$ values. The obtained parameter values represent the mid-point of each 15-day period, and were interpolated for the missing periods in daily steps.

The parameters of the NEE model (Eq. 4) were also estimated for 15-day subsets shifting the window five days at a time. The values obtained from this were only accepted if the number of the measured flux values was larger than 100 and the parameter values were not considered unrealistic

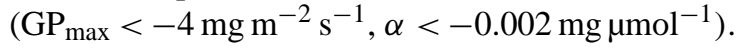

In winter, $R_{\text {tot }}$ was modelled by fitting Eq. (2) to the night-time (PPFD $<1 \mu \mathrm{mol} \mathrm{m}^{-2} \mathrm{~s}^{-1}$ ) $\mathrm{CO}_{2}$ flux data, to avoid data with photosynthetic $\mathrm{CO}_{2}$ uptake. This time, $E_{0}$ and $T_{\text {ref }}$ were derived commonly from all winter data (17 November 2004-30 March 2005 and 16 November-31 December 2005). Using the resulting parameter values $\left(R_{\text {ref }}=0.0603 \mathrm{mg} \mathrm{CO}_{2} \mathrm{~m}^{-2} \mathrm{~s}^{-1}\right.$ and $\left.E_{0}=136 \mathrm{~K}\right)$ and $T_{\text {air }}$, the half-hourly $R_{\text {tot }}$ was calculated. Thereafter, Eq. (4) (without $f_{\mathrm{VPD}}$ ) was fitted to the NEE data measured when $T_{\text {air }}>-3^{\circ} \mathrm{C}$ from 18 November 2004 31 January 2005 (the period when photosynthesis was observed) using the modelled $R_{\text {tot }}$ as an input value. The $\alpha$ and $\mathrm{GP}_{\max }$ obtained from this were used to reconstruct NEE for both winter periods, for half-hour periods with $T_{\text {air }}>-3{ }^{\circ} \mathrm{C}$. With $T_{\text {air }}<-3{ }^{\circ} \mathrm{C}$ the modelled respiration rate was used for gap-filling.

For the 10-day gap in spring 2005, the daily modelled $R_{\text {tot }}$ and GPP and their correlation with air temperature and irradiation, respectively, were used. In addition, since the emergence of photosynthesis after the winter occurred during this gap, we used a linearly increasing photosynthesis factor in the gap-filling of GPP data. This factor was given a value from 0 to 1 , which was derived from the difference between the average GPP of the five days preceding and following the gap.

\section{Appendix B}

\section{Uncertainty analysis}

\section{B1 Estimation of the uncertainty in the annual $\mathrm{CO}_{2}$ balance}

The uncertainty of the $\mathrm{CO}_{2}$ balance was evaluated following the procedure presented by Aurela et al. (2002). The random error, estimated from the difference between the measured and modelled values, was $1.1 \%$ of the annual $\mathrm{CO}_{2}$ balance. Considering the systematic errors, the gap-filling of the longer ( $>2$ days) gaps in the growing season flux data was the largest error source, resulting in an uncertainty of $10.7 \%$ of the annual balance. This was estimated by recalculating the balance for these missing periods by shifting the model parameters by 15 days forward and backward, and calculating the difference between the original and recalculated balances. For each measurement gap, differences resulting from the forward and backward shifts were averaged, and the total error was calculated by summing the absolute values of these averages. In winter, the uncertainty due to gap-filling was estimated by comparing the balances obtained using the photosynthesis model to those obtained using the respiration model only (see Ch. 3.3), resulting in an error of $2.5 \%$ of the annual balance. In addition, we included the systematic error arising from the high frequency loss and the respective corrections (Aurela et al., 2002). At our site, this error was estimated to contribute to $3 \%$ of the annual balance. The uncertainty related to the selection of the $u_{*}$ criterion was not included here, since setting the limit to $0.10 \mathrm{~m} \mathrm{~s}^{-1}$ was unambiguous, and there was no reason for selecting a different criterion. The total relative uncertainty in the annual balance was calculated by combining the different errors (in \%) using the error propagation principle:

$$
\begin{aligned}
& \pm \sqrt{1.1^{2}+10.7^{2}+2.5^{2}+3.0^{2}} \% \\
& = \pm 11.4 \%\left( \pm 100 \mathrm{~g} \mathrm{CO}_{2} \mathrm{~m}^{-2} \mathrm{yr}^{-1}\right)
\end{aligned}
$$

\section{B2 Estimation of the standard error of the annual tree biomass increment}

Tree stand biomass for the years 2005 and 2000 was estimated using single tree biomass models of Laiho and Finér (1996; see Tobin et al., 2007) for the pine belowground biomass and the models of Repola (2008, 2009) for other biomass components. Repola $(2008,2009)$ reports the normally distributed random variance of the natural logarithm of the biomass component $y$ of the tree $i\left[\operatorname{var}\left(\ln y_{i}\right)\right]$ as the sum of within-stand random variance $[\operatorname{var}(e)]$ and between stand random variance $[\operatorname{var}(u)]$. var $(u)$ equals the within-stand covariance $\left[\operatorname{cov}\left(\ln y_{i}, \ln y_{j}\right)\right]$.

From this follows that $\operatorname{var}\left(y_{i}\right)$ and $\operatorname{cov}\left(y_{i}, y_{j}\right)$ are those of the bivariate lognormal distribution (Mostafa and Mahmoud, 1964):

$\operatorname{var}\left(y_{i}\right)=y_{i}^{2}\left(e^{\operatorname{var}(u)+\operatorname{var}(e)}-1\right)$

and

$\operatorname{cov}\left(y_{i}, y_{j}\right)=y_{i} y_{j}\left(e^{\operatorname{var}(u)}-1\right)$

Variance of the stand biomass of component $y$ ( $n$ trees in the stand) is then calculated as:

$\operatorname{var}\left(\sum_{i=1}^{n} y_{i}\right)=\sum_{i=1}^{n} \operatorname{var}\left(y_{i}\right)+\sum_{i=1}^{n} \sum_{i \neq j} \operatorname{cov}\left(y_{i}, y_{j}\right)$

The $\operatorname{var}\left(y_{i}\right)-\operatorname{cov}\left(y_{i}, y_{j}\right)$ ratio for pine above ground biomass (Repola, 2009) is also applied to pine below ground biomass as Laiho and Finér (1996) do not report the between tree covariance.

Variances of the stand biomass components are then summed taking into consideration the between-component correlations reported by Repola (2008, 2009). Considering 
that the variances of the stand biomasses of the same stand for the years 2000 and 2005 must be highly correlated, random variance for the biomass increment in the five years is estimated by subtracting the random variance of the biomass in 2000 from that in 2005. Finally, the standard error (SE) of the annual tree biomass increment is calculated as $1 / 5$ of the square root of the variance of the five-year biomass increment. The SE caused by measuring 33 plots instead of the whole tree stand $(4.1 \%)$ was also added to the SE, resulting in a total relative error of $20 \%\left(=130 \mathrm{~g} \mathrm{CO}_{2} \mathrm{~m}^{-2} \mathrm{yr}^{-1}\right)$.

Acknowledgements. The Kalevansuo site was set up during the Research Program "Greenhouse Impacts of the Use of Peat and Peatlands in Finland" (2002-2005), with funding from Ministry of Agriculture and Forestry and Ministry of Trade and Industry. The financial support by the European Commission through the projects NitroEurope (017841) and GHG Europe (244122), and by the Academy of Finland Centre of Excellence program (project 1118615) are gratefully acknowledged. Thanks are due to Arska Halm for technical help, Juha Hatakka for constructing the data acquisition system and Minna Pulkkinen for advice on bivariate lognormal distributions. Tiina Badorek, Raimo Jaatinen, Soili Kojola, Timo Haikarainen, Ismo Kyngäs, Inkeri Suopanki and Tea Thum are thanked for the field work, data processing and maintenance of the measurements. We are grateful to Sotainvalidien veljesliitto (Disabled War Veterans Association of Finland) for allowing us to draw a power cable from their premises. Metsähallitus (Finnish Forest and Park Service) is acknowledged for permitting the establishment of the study site on their land.

Edited by: A. Neftel

\section{References}

Aurela, M., Laurila, T., and Tuovinen, J.-P.: Annual $\mathrm{CO}_{2}$ balance of a subarctic fen in northern Europe: Importance of the wintertime efflux, J. Geophys. Res., 107, 4607, doi:10.1029/2002JD002055, 2002.

Aurela, M., Riutta, T., Laurila, T., Tuovinen, J.-P., Vesala, T., Tuittila, E.-S., Rinne, J., Haapanala, S., and Laine, J.: $\mathrm{CO}_{2}$ exchange of a sedge fen in southern Finland - the impact of a drought period, Tellus, 59B, 826-837, 2007.

Aurela, M., Lohila, A., Tuovinen, J.-P., Hatakka, J., Riutta, T., and Laurila, T.: Carbon dioxide exchange on a northern boreal fen, Boreal Environ. Res., 14, 699-710, 2009.

Badorek, T., Tuittila, E.-S., Ojanen, P., and Minkkinen, K.: Forest floor photosynthesis and respiration in a drained peatland forest in southern Finland, Plant Ecol. Div., in preparation, 2011.

Dinsmore, K. J., Billet, M. F., Skiba, U. M., Rees, R. M., Drewer, J., and Helfter, C.: Role of the aquatic pathway in the carbon and greenhouse gas budgets of a peatland catchment, Global Change Biol., 16, 2750-2762, 2010.

Domisch, T., Finér, L., Laiho, R., Karsisto, M., and Laine, J.: Decomposition of Scots pine litter and the fate of released carbon in pristine and drained pine mires, Soil Biol. Biochem., 32, 15711580, 2000.
Drebs, A., Nordlund, A., Karlsson, P., Helminen, J., and Rissanen, P.: Climatological statistics of Finland 1971-2000, Climatic Statistics of Finland 2002:1, Finn. Meteorol. Inst., Helsinki, Finland, 2002.

Flanagan, L. B. and Syed, K. H.: Stimulation of both photosynthesis and respiration in response to warmer and drier conditions in a boreal peatland ecosystem, Global Change Biol., 17, 2271-2287, doi:10.1111/j.1365-2486.2010.02378.x, 2011.

Forster P., Ramaswamy, V., Artaxo, P., Berntsen, T., Betts, R., Fahey, D. W., Haywood, J., Lean, J., Lowe, D. C., Myhre, G., Nganga, J., Prinn, R., Raga, G., Schulz, M., and Van Dorland, R.: Changes in Atmospheric Constituents and in Radiative Forcing, in: Climate Change 2007: The Physical Science Basis. Contribution of Working Group I to the Fourth Assessment Report of the Intergovernmental Panel on Climate Change, edited by: Solomon, S., Qin, D., Manning, M., Chen, Z., Marquis, M., Averyt, K. B., Tignor, M., and Miller, H. L., 129-234, Cambridge University Press, Cambridge, 2007.

Hargreaves, K. J., Milne, R., and Cannell, M. G. R.: Carbon balance of afforested peatland in Scotland, Forestry, 76, 299-317, 2003.

Hökkä, H., Repola, J., and Laine, J.: Quantifying the interrelationship between tree stand growth rate and water table level in drained peatland sites within Central Finland, Can. J. Forest Res., 38, 1775-1783, 2008.

Ilvesniemi, H., Levula, J., Ojansuu, R., Kolari, P., Kulmala, L., Pumpanen, J., Launiainen, S., Vesala, T., and Nikinmaa, E.: Long-term measurements of the carbon balance of a boreal Scots pine dominated forest ecosystem, Boreal Environ. Res., 14, 731753, 2009.

Kaimal, J. C. and Finnigan, J. J.: Atmospheric Boundary Layer Flows. Their Structure and Measurement, Oxford University Press, New York, 304 pp., 1994.

Keltikangas, M., Laine, J., Puttonen, P., and Seppälä, K.: Vuosina 1930-1978 metsäojitetut suot: ojitusalueiden inventoinnin tuloksia (Summary: Peatlands drained for forestry during 1930-1978: results from field surveys of drained areas), Acta Forestalia Fennica, 193, 94 pp., 1986.

Koehler, A. K., Sottocornola, M., and Kiely, G.: How strong is the current carbon sequestration of an Atlantic blanket bog?, Global Change Biol., 17, 309-319, 2011.

Kormann, R. and Meixner, F. X.: An analytical footprint model for non-neutral stratification, Boundary-Layer Meteorol., 99, 207224, 2001.

Kortelainen, P., Saukkonen, S., and Mattsson, T.: Leaching of nitrogen from forested catchments in Finland, Global Biogeochem. Cy., 11, 627-638, 1997.

Lafleur, P. M., Roulet, N. T., Bubier, J. L., Frolking, S., and Moore T. L.: Interannual variability in the peatland-atmosphere carbon dioxide exchange at an ombrotrophic bog, Global Biogeochem. Cy., 17, 1036, doi:10.1029/2002GB001983, 2003.

Laiho, R. and Finér, L.: Changes in root biomass after water-level drawdown on pine mires in southern Finland, Scand. J. Forest Res., 11, 251-260, 1996.

Laiho, R., Vasander, H., Penttilä, T., and Laine, J.: Dynamics of plant-mediated organic matter and nutrient cycling following water-level drawdown in boreal peatlands, Global Biogeochem. Cy., 17, 1053, doi:10.1029/2002GB002015, 2003.

Laine, J., Laiho, R., Minkkinen, K., and Vasander, H.: Forestry and Boreal Peatlands, in: Boreal Peatland Ecosystem, edited by: 
Kelman, W. R. and Vitt, D. H., Ecological Studies 188, 331359, Springer-Verlag, Berlin - Heidelberg, ISBN 3-540-31912-3, 2006.

Lappalainen, E.: Peatlands and peat resources in Finland, in: Peatlands in Finland, edited by: Vasander H., Finnish Peatland Society, Helsinki, Finland, 198 pp., 1996.

Lasslop, G., Reichstein, M., Papale, D., Richardson, A. D., Arneth, A., Barr, A., Stoy, P., and Wohlfahrt, G.: Separation of net ecosystem exchange into assimilation and respiration using a light response curve approach: critical issues and global evolution, Global Change Biol., 16, 187-208, 2010.

Laurila, T., Tuovinen, J.-P., Lohila, A., Hatakka, J., Aurela, M., Thum, T., Pihlatie, M., Rinne, J., and Vesala, T.: Measuring methane emissions from a landfill using a cost-effective micrometeorological method, Geophys. Res. Lett., 32, L19808, doi:10.1029/2005GL023462, 2005.

Lindroos, A.-J., Derome, J., Mustajärvi, K., Nöjd, P., Beuker, E., and Helmisaari, H.-S.: Fluxes of dissolved organic carbon in stand throughfall and percolation water in 12 boreal coniferous stands on mineral soils in Finland, Boreal Environ. Res., 13B, 22-34, 2008.

Lloyd, J. and Taylor, J. A.: On the temperature dependence of soil respiration, Funct. Ecol., 8, 315-323, 1994.

Lohila, A., Aurela, M., Tuovinen, J.-P., and Laurila, T.: Annual $\mathrm{CO}_{2}$ exchange of a peat field growing spring barley or perennial forage grass, J. Geophys. Res., 109, D18116, doi:10.1029/2004JD004715, 2004.

Lohila, A., Laurila, T., Aro, L., Aurela, M., Tuovinen, J.-P., Laine, J., Kolari, P., and Minkkinen, K.: Carbon dioxide exchange above a 30-year-old Scots pine plantation established on organicsoil cropland, Boreal Environ. Res., 12, 141-157, 2007.

Lund, M., Lindroth, A., Christensen, T. R., and Ström, L.: Annual $\mathrm{CO}_{2}$ balance of a temperate bog, Tellus, 59B, 704-811, 2007.

Luyssaert, S., Janssens, I. A., Sulkava, M., Papale, D., Dolman, A. J., Reichstein, M., Hollmen, J., Martin, J. G., Suni, T., Vesala, T., Loustau, D., Law, B. E., and Moors, E. J.: Photosynthesis drives anomalies in net carbon-exchange of pine forests at different latitudes, Global Change Biol., 13, 2110-2127, 2007.

Maljanen, M., Martikainen, P. J., Walden, J., and Silvola, J.: $\mathrm{CO}_{2}$ exchange in an organic field growing barley or grass in eastern Finland, Global Change Biol., 7, 679-692, 2001.

Martikainen, P. J., Nykänen, H., Crill, P., and Silvola, J.: Effect of a lowered water table on nitrous oxide fluxes from northern peatlands, Nature, 366, 51-53, 1993.

Martikainen, P. J., Nykänen, H., Alm, J., and Silvola, J.: Change in fluxes of carbon dioxide, methane and nitrous oxide due to forest drainage of mire sites of different trophy, Plant Soil, 168-169, 571-577, 1995.

Mills, G., Pleijel, H., Büker, P., Braun, S., Emberson, L., Harmens, H., Hayes, F., Simpson, D., Grünhage, L., Karlsson, P.-E., Danielsson, H., Bermejo, V., and Gonzalez Fernandez, I.: Mapping Critical Levels for Vegetation, in: Manual on Methodologies and Criteria for Modelling and Mapping Critical Loads \& Levels and Air Pollution Effects, Risks and Trends, http://www.rivm.nl/en/themasites/icpmm/ manual-and-downloads/manual-english/index.html, 2010.

Minkkinen, K.: Effect of forestry drainage on the carbon balance and radiative forcing of peatlands in Finland, Academic dissertation, Vammalan Kirjapaino Oy, Vammala, Finland, 1999.
Minkkinen, K. and Laine, J.: Long-term effect of forest drainage on the peat carbon stores of pine mires in Finland, Canadian J. For. Res., 28, 1267-1275, 1998.

Minkkinen, K., Vasander, H., Jauhiainen, S., Karsisto, M., and Laine, J.: Post-drainage changes in vegetation composition and carbon balance in Lakkasuo mire, central Finland, Plant Soil, 207, 107-120, 1999.

Minkkinen, K., Korhonen, R., Savolainen, I., and Laine, J.: Carbon balance and radiative forcing of Finish peatlands 1900-2100 the impact of forestry drainage, Global Change Biol., 8, 785799, 2002.

Minkkinen, K., Laine, J., Shurpali, N., Mäkiranta, P., Alm, J., and Penttilä, T.: Heterotrophic soil respiration in forestry-drained peatlands, Boreal Environ. Res., 12, 115-126, 2007a.

Minkkinen, K., Penttilä, T., and Laine, J.: Tree stand volume as a scalar for methane fluxes in forestry-drained peatlands in Finland, Boreal Environ. Res., 12, 127-132, 2007b.

Minkkinen, K., Byrne, K. A., and Trettin, C.: Climate impacts of peatland forestry, in: Peatlands and Climate Change, edited by: Strack, M., International Peat Society, Saarijärvi, Finland, 98122, 2008.

Montanarella, L., Jones, R. J. A., and Hiederer, R.: The distribution of peatland in Europe, Mires Peat, 1, 1-10, 2006.

Moore, C. J.: Frequency response corrections for eddy correlation systems, Boundary-Layer Meteorol., 37, 17-35, 1986.

Mostafa, M. D. and Mahmoud, M. W.: On the problem of estimation for the bivariate lognormal distribution, Biometrika, 51, 522-527, 1964.

Moyano, F. E., Atkin, O. K., Bahn, M., Bruhn, D., Burton, A. J., Heinemeyer, A., Kutsch, W. L., and Wieser, G.: Respiration from roots and the mycorrhizosphere, in: Soil carbon dynamics - an integrated methodology, edited by: Kutsch, W. L., Bahn, M. and Heinemeyer, A., Cambridge University Press, Cambridge, U.K., 2009.

Nykänen, H., Alm, J., Lång, K., Silvola, J., and Martikainen, P. J.: Emissions of $\mathrm{CH}_{4}, \mathrm{~N}_{2} \mathrm{O}$ and $\mathrm{CO}_{2}$ from a virgin fen and a fen drained for grassland in Finland, J. Biogeogr., 22, 351-357, 1995.

Ojanen, P., Minkkinen, K., Alm, J., and Penttilä, T.: Soilatmosphere $\mathrm{CO}_{2}, \mathrm{CH}_{4}$ and $\mathrm{N}_{2} \mathrm{O}$ fluxes in boreal forestry-drained peatlands, For. Ecol. Manage., 260, 411-421, 2010.

Pihlatie, M. K., Kiese, R., Brüggemann, N., Butterbach-Bahl, K., Kieloaho, A.-J., Laurila, T., Lohila, A., Mammarella, I., Minkkinen, K., Penttilä, T., Schönborn, J., and Vesala, T.: Greenhouse gas fluxes in a drained peatland forest during spring frost-thaw event, Biogeosciences, 7, 1715-1727, doi:10.5194/bg-7-17152010, 2010.

Rantakari, M., Mattsson, T., Kortelainen, P., Piirainen, S., Finér, L., and Ahtiainen, M.: Organic and inorganic carbon concentrations and fluxes from managed and unmanaged boreal first-order catchments, Sci. Total Environ., 408, 1649-1658, 2010.

Regina, K., Nykänen, H., Silvola, J., and Martikainen, P. J.: Fluxes of nitrous oxide from boreal peatlands as affected by peatland type, water table level and nitrification capacity, Biogeochemistry, 35, 401-418, 1996.

Repola, J.: Biomass equations for birch in Finland, Silva Fennica, 42, 605-624, 2008.

Repola, J.: Biomass equations for Scots pine and Norway spruce in Finland, Silva Fennica, 43, 625-647, 2009. 
Saarnio, S., Morero, M., Shurpali, N. J., Tuittila, E.-S., Mäkilä, M., and Alm, J.: Annual $\mathrm{CO}_{2}$ and $\mathrm{CH}_{4}$ fluxes of pristine boreal mires as a background for the lifecycle analysis of peat energy, Boreal Environ. Res., 12, 101-114, 2007.

Sallantaus, T. and Kaipainen, H.: Water-carried element balances of peatlands, in: Northern peatlands in global climatic change, edited by: Laiho, R., Laine, J., and Vasander, H., Publications of the Academy of Finland, Edita, Helsinki, 197-203, 1996.

Sarkkola, S., Koivusalo, H., Laurén, A., Kortelainen, P., Mattsson, T., Palviainen, M., Piirainen, S., Starr, M., and Finér, L.: Trends in hydrometeorological conditions and stream water organic carbon in boreal forested catchments, Sci. Total Environ., 408, 92$101,2009$.

Sevanto, S., Suni, T., Pumpanen, J., Grönholm, T., Kolari, P., Nikinmaa, E., Hari, P., and Vesala, T.: Wintertime photosynthesis and water uptake in a boreal forest, Tree Physiol. 26, 749-757, 2006.

Silvola, J., Alm, J., Ahlholm, U., Nykänen, H., and Martikainen, P. J.: $\mathrm{CO}_{2}$ fluxes from peat in boreal mires under varying temperature and moisture conditions, J. Ecol., 84, 219-228, 1996.

Straková, P., Anttila, J., Spetz, P., Kitunen, V., Tapanila, T., and Laiho, R.: Litter quality and its response to water level drawdown in boreal peatlands at plant species and community level, Plant Soil, 335, 501-520, 2010.

Straková, P., Penttilä, T., Laine, J., and Laiho, R.: Disentangling direct and indirect effects of water table drawdown on above- and belowground plant litter decomposition: consequences for accumulation of organic matter in boreal peatlands, Global Change Biol., doi:10.1111/j.1365-2486.2011.02503.x, in press, 2011.
Syed, K. H., Flanagan, L. B., Carlson, P. J., Glenn, A. J., and Van Gaalen, K. E.: Environmental control of net ecosystem $\mathrm{CO}_{2}$ exchange in a treed, moderately rich fen in northern Alberta, Agric. For. Met., 140, 97-114, 2006.

Tobin, B., Èermák, J., Chiatante, D., Danjon, F., Di Iorio, A., Dupuy, L., Eshel, A., Jourdan, C., Kalliokoski, T., Laiho, R., Nadezhdina, N., Nicoll, B., Pagès, L., Silva, J., and Spanos, I.: Towards developmental modelling of tree root systems, Plant Biosystems, 141, 481-501, 2007.

Turetsky, M. R. and St. Louis, V. L.: Disturbance in boreal peatlands, in: Boreal Peatland Ecosystems, edited by: Wieder, R. K. and Vitt, D. H., Ecological Studies, 188, Springer-Verlag, Berlin Heidelberg, 2006.

Veenendaal, E. M., Kolle, O., Leffelaar, P. A., Schrier-Uijl, A. P., Van Huissteden, J., Van Walsem, J., Möller, F., and Berendse, F.: $\mathrm{CO}_{2}$ exchange and carbon balance in two grassland sites on eutrophic drained peat soils, Biogeosciences, 4, 1027-1040, doi:10.5194/bg-4-1027-2007, 2007.

Webb, E. K., Pearman, G. I., and Leuning, R.: Correction of flux measurements for density effects due to heat and water vapour transfer, Q. J. R.. Meteorol. Soc., 106, 85-100, 1980.

Wilson, K., Goldstein, A., Falge, E., Aubinet, M., Baldocchi, D., Berbigier, P., Bernhofer, C., Ceulemans, R., Dolman, H., Field, C., Grelle, A., Ibrom, A., Law, B. E., Kowalski, A., Meyers, T., Moncrieff, J., Monson, R., Oechel, W., Tenhunen, J., Valentini, R., and Verma, S.: Energy balance closure at FLUXNET sites, Agric. For. Meteorol., 113, 223-243, 2002. 